\title{
CLIMATE CHANGE IN QUEENSLAND'S GRAZING LANDS: II. AN ASSESSMENT OF THE IMPACT ON ANIMAL PRODUCTION FROM NATIVE PASTURES
}

\author{
W.B. Hall', G.M. McKeon', J.O. Carter'1, K.A. Day', S.M. Howden ${ }^{2}$, J.C. Scanlan', \\ P.W. Johnston ${ }^{4}$ and W.H. Burrows ${ }^{5}$
}

${ }^{1}$ Climate Impacts and Grazing Systems, Queensland Department of Natural Resources, 80 Meiers Rd Indooroopilly, Qld, Australia 4068.

${ }^{2}$ CSIRO Wildlife and Ecology, GPO Box 284, Canberra, ACT, Australia 2601.

${ }^{3}$ Robert Wicks Research Centre, Queensland Department of Natural Resources, PO Box 318 , Toowoomba, Qld, Australia 4350.

${ }^{+}$Sheep and Wool Institute, Queensland Department of Primary Industries, GPO Box 3129, Brisbane, Qld, Australia 4001.

${ }^{5}$ Queensland Beef Institute, Queensland Department of Primary Industries, PO Box 5545, Rockhampton, Qld, Australia 4702.

\section{Abstract}

The 160 million ha of grazing land in Queensland support approximately 10 million beef equivalents (9.8 million cattle and 10.7 million sheep) with treed and cleared native pastures as the major forage source. The complexity of these biophysical systems and their interaction with pasture and stock management, economic and social forces limits our ability to easily calculate the impact of climate change scenarios. We report the application of a systems approach in simulating the flow of plant dry matter and utilisation of forage by animals. Our review of available models highlighted the lack of suitable mechanistic models and the potential role of simple empirical relationships of utilisation and animal production derived from climatic and soil indices.

Plausible climate change scenarios were evaluated by using a factorial of rainfall $( \pm 10 \%) * 3^{\circ} \mathrm{C}$ temperature increase * doubling $\mathrm{CO}_{2}$ in sensitivity studies at property, regional and State scales. Simulation of beef cattle liveweight gain at three locations in the Queensland black speargrass zone showed that a $\pm 10 \%$ change in rainfall was magnified to be a $\pm 15 \%$ change in animal production (liveweight gain per ha) depending on location, temperature and $\mathrm{CO}_{2}$ change. Models of 'safe' carrying capacity were developed from property data and expert opinion. Climate change impacts on 'safe' carrying capacity varied considerably across the State depending on whether moisture, temperature or nutrients were the limiting factors. Without the effect of doubling $\mathrm{CO}_{2}$, warmer temperatures and $\pm 10 \%$ changes in rainfall resulted in -35 to $+70 \%$ changes in 'safe' carrying capacity depending on location With the effect of doubling $\mathrm{CO}_{2}$ included, the changes in 'safe' carrying capacity ranged from -12 to $+115 \%$ across scenarios and locations. When aggregated to a whole-of-State carrying capacity, the combined effects of warmer temperature, doubling $\mathrm{CO}_{2}$ and $\pm 10 \%$ changes in rainfall resulted in 'safe' carrying capacity changes of +3 to $+45 \%$ depending on rainfall scenario and location. A major finding of the sensitivity study was the potential importance of doubling $\mathrm{CO}_{2}$ in mitigating or amplifying the effects of warmer temperatures and changes in rainfall. Field studies on the impact of $\mathrm{CO}_{2}$ are therefore a high research priority.

Keywords: climate change, Queensland, simulation, rangelands, beef production, cattle, carrying capacity, $\mathrm{CO}_{2}$, utilisation

\section{Introduction}

In Part I (McKeon et al. 1998c) we described the importance of climate change as an issue for rangeland users and documented the temporal trends in climate variables averaged across Queensland's grazing lands. The review in Part I also suggested that the low priority of climate change issues, as perceived by the users of rangelands, was in part due to a lack of information on global climate change and current climatic trends, and a lack of knowledge of the potential impact of climate change on grazing industries. 
In Part II we conduct a systems analysis of extensive grazing industries in Queensland focusing on those factors that are likely to be impacted by climate change. We then review models of Queensland's sheep and cattle industries from the viewpoint of quantifying the impact of climatic variation and change on sheep and beef cattle production from Queensland's native pastures. Sheep and cattle models are evaluated in terms of: 1) individual animal production; 2) estimation of regional 'safe' carrying capacity; and 3) State-wide 'safe' carrying capacity.

\section{Systems analysis of extensive grazing industries in Queensland}

The extensive grazing lands of Queensland are currently (1996) grazed by 9.8 million cattle and 10.7 million sheep (Australian Bureau of Statistics). Peak cattle and sheep numbers occurred in 1976-78 (11 million) and 1964-65 (24 million) respectively. The gross value of Queensland's rural production from beef cattle and sheep for 1995-96 was estimated at $\$ 1438$ million being $25 \%$ of the total gross value of Queensland's primary industries (\$5765 million, Whybrow 1997).

In the 1980 s, native pastures accounted for $87 \%$ of Queensland's 173 million ha (Lloyd and Burrows 1988). The majority of beef cattle and nearly all sheep in Queensland were located on native pastures in contrast to most Australian States where stock were concentrated on introduced pastures in the high rainfall and wheat-sheep zones (Mott et al. 1981). Major vegetation changes occurring in the 1990s in native pastures include woodland thickening (Burrows 1995), buffel grass spreading (O'Rourke et al. 1992), loss of desirable perennial grasses and weed invasion (Tothill and Gillies 1992).

To determine the sensitivity of the extensive grazing industries to spatial and temporal variation in climate we have adopted a systems approach (e.g. Campbell et al. 1996, 1997) describing the grazing system as a flow of plant dry matter (carbon) and nutrients (nitrogen and phosphorus) that determines both carrying capacity (animals per ha) and production per head (including wool, meat, births and mortalities). The biophysical components of the grazing system are climate, soils and plant species which interact to produce the plant dry matter consumed by sheep and cattle for maintenance and production.

Other important factors impacting on the productivity and profitability of grazing enterprises both directly and indirectly, and likely to be affected by climate change, are: pests, diseases, weeds, markets, prices, costs, vegetation change including woodland thickening, land degradation, fire management, and alternative land uses such as cropping and carbon sequestration.

A general description of the cattle and sheep industries including history, husbandry practices and productivity has been given by Gramshaw and Lloyd (1993). A more detailed description of beef production systems has been provided by O'Rourke et al. (1992) who collated the survey responses of 2165 beef producers in northern Australia ( $>2000$ in Queensland) summarising the data for 14 regions including 12 in Queensland. They found that there were substantial differences between the 12 Queensland regions in terms of both biophysical and management attributes and thus climate change impact studies need to account for this regional variation.

\section{Factors affecting animal nutrition on native pastures}

Animal production requires intake of plant dry matter (carbon) and nutrients (nitrogen and phosphorus). Low concentration of these nutrients and/or a high content of stem material in the diet can restrict intake (Poppi et al. 1981), and hence production. Native pastures have the following major features relevant to animal nutrition: 
1. nutrient concentrations (nitrogen and phosphorus) in most native plant parts, with the exception of young leaves and seeds, are relatively low (McLennan et al. 1988);

2. most native pastures are dominated by $\mathrm{C}_{4}$ grasses (Hattersley 1983) which have relatively low protein concentrations and a high proportion of stem at the end of the summer growing season; and

3. growth of $\mathrm{C}_{4}$ grasses during winter is limited by temperature (Ivory and Whiteman 1978, Mott et al. 1985) and most are susceptible to frost resulting in rapid decline in nutrient value (Wilson and Mannetje 1978).

Since native pastures occur in climatic zones which have either 1) high year-to-year variability in seasonal and annual rainfall, or 2) strong seasonality with a long dry season (e.g. northern Queensland, top end of Northern Territory), the plant components with low nutritional quality (senesced and 'old green' material) are often the predominant forage classes available to stock for extended periods of time.

Animal production attributes (i.e. liveweight gain of cattle and sheep, wool growth of sheep, flock/herd reproduction and mortality) are strongly related to the availability of young plant material (Mannetje 1974, Ash et al. 1982, McLennan et al. 1988), which in turn is controlled by the frequency of climatic conditions being suitable for plant growth. Exceptions to this generality occur where the animals are able to select high quality diets from different plant components, plant species within the sward, edible shrubs, or landscape units within a paddock. $\mathrm{C}_{3}$ species (grasses and forbs) can, at times, make up an important high quality component of an animals diet (Beale 1975, McMeniman et al. 1986a, b, A.J. Ash, pers. comm.). Grazing history and pasture management (burning, tree regrowth control) can also have major impacts on botanical composition and hence diet quality (e.g. McMeniman et al. 1986a, b, Orr 1986, Ash et al. 1995). Because animal nutrition is likely to be limited by the availability of plant components of adequate nutrient levels during dry or winter periods, graziers may have to adopt relatively low stocking rates to achieve reproductive rates high enough to maintain self-replacing herds and flocks. Thus changes in the growing period of pastures and/or pasture composition as a result of climate change will have pervasive impacts on animal production. Nevertheless there are also other limiting factors in certain areas of the grazing lands such as phosphorus deficiency (McLean et al. 1990, O'Rourke et al. 1992, McCosker and Winks 1994) which are likely to persist under climate change.

\section{Pests, diseases and weeds}

Climate-driven models of the temporal and spatial distribution of pests, diseases and weeds have been developed for some key species and reviewed by Sutherst et al. (1996), e.g. the biting midge Culicoides waadia which is a vector of bluetongue virus in Australia, the temperate livestock tick Haemaphysalis longicornis, and the tropical cattle tick Boophilus microplus. Potential climate change impacts on buffalo fly and sheep blowfly have also been inferred (Sutherst 1990). However, Sutherst et al. (1996) note that whilst it may be possible to model, for example, tick numbers, these effects cannot be assessed at the enterprise level until direct climatic effects on pasture and animals have been estimated. As a necessary first step in this assessment we have collated below a number of case studies to provide examples of impacts under the current climatic environment.

1) McLeod (1995) estimated that cattle ticks, which are endemic in northern tropical grazing lands, cost the beef cattle industry $\$ 41$ million annually in control measures and $\$ 91$ million in productivity losses through reduced liveweight gain (LWG) and increased mortalities. The combined cost was $7 \%$ of the gross value of cattle production in Queensland for 1993-94 (\$1829 million, Whybrow 1997).

2) McLeod (1995) estimated that roundworms, lice and blowflies cost the Australian sheep industry $\$ 552$ million annually in control measures and production losses representing 
$17 \%$ of total gross value from the combined wool ( $\$ 2449$ million) and sheep-meat ( $\$ 758$ million) sectors (ABARE 1996).

3) The cost of weeds to the Australian wool industry was estimated at $10 \%$ of the value of the total woolclip (ARMCANZ 1996).

4) Mackey (1996) estimated the woody weed Acacia nilotica reduced the income from grazing in the five worst affected shires of northern Queensland by $3 \%$.

5) Chippendale and Panetta (1994) estimated the cost of parthenium weed to the Queensland cattle industry was $\$ 16.5$ million annually with a reduction in regional cattle production of $7 \%$.

Apart from the direct impact of diseases on sheep and cattle there are also important human health considerations in the grazing lands, e.g. Ross River virus, Murray Valley encephalitis virus and malaria (Bryan et al. 1996, Lindsay and Mackenzie 1997). Direct effects of climate extremes (e.g. high temperature) on human mortality have also been documented (McMichael et al. 1996).

Sutherst et al. (1996) argued that research in this important area of climate change impacts is fragmented and under-resourced. Given the potential impacts of pests and diseases on production and markets this lack of risk analysis is disturbing. A major danger is that the potential distribution of pests, diseases and weeds may change gradually, for example, with increasing temperature and go undetected until episodic events trigger widespread outbreaks. Near real-time systems (e.g. Atzeni et al. 1997, Carter et al. 1998) which regularly re-calculate potential distribution based on changing climate could be combined with existing monitoring systems to provide the basis for more rapid reaction.

\section{Vegetation change, markets, prices and costs}

The impact of climatic variation on the other components of grazing systems: vegetation change, woodland thickening, land degradation, fire management, markets, prices and costs are even more difficult to assess than pests, diseases and weeds. In most of these cases it is difficult to separate climatic and managerial effects, e.g. the current debate over vegetation thickening in relation to the National Greenhouse Gas Inventory (Burrows 1995, Fensham 1998)

The processes of vegetation change have been modelled for eucalypts in central Queensland (GRASSMAN, Clewett et al. 1991) and mulga (Moore et al. 1997) but are still being adapted for other pasture communities. The simulation of climate change impacts will require not only models of the effects on plant species and interaction between species, but also models of management response (stocking rate and fire regime) to changes in the condition of the grazing resource, economic pressures and government policies (e.g. drought, 'exceptional circumstances' and greenhouse gas emissions).

Global climate change impacts can also feasibly affect Queensland's grazing industries. For example, shorter winters in the northern hemisphere (Keeling et al. 1996, Myneni et al. 1997) may alter global demand for wool. In the case of meat, prices received by Queensland graziers are strongly influenced by production of overseas competitors (including world grain production) and hence global climate change impacts are likely to influence the financial performance of Queensland grazing enterprises (White 1972, Herne 1998).

\section{Spatial distribution of the Queensland wool industry}

The above analysis highlights the wide range of components through which climate change can influence the performance of individual grazing enterprises and the spatial distribution of viable enterprises. For example, the existing geographic distribution of the Queensland sheep industry has been used to derive various climatic indices (e.g. Farmer et al. 1947) and to predict future climate change impacts on distribution (Graetz et al. 1988). However, many factors have led to the current distribution and in many cases it is not possible to separate the effects of climate from other constraints. 
For some regions of Australia, history has played a major role in determining the presence or absence of sheep enterprises in these areas today. Because of the greater relative value of wool to cattle production in the late 19th and early part of the 20th century, sheep were introduced at some stage to most areas, e.g. the introduction of sheep at Victoria River Downs in the Northern Territory in 1890 was successful for a few years but the flock was sold to a property on unsuitable country and died off. Makin (1992), without the benefit of foresight of the current low wool prices, stated "For the Northern Territory, this was one of the greatest tragedies of all time. Had the sheep been kept on the Victoria there is every likelihood that stations now carrying cattle would also be counted as wool producers." Thus, caution should be exercised in using existing geographical distribution of an industry to derive climatic constraints.

Nevertheless, strong climatic effects can be identified at the boundaries of the sheep industry in Queensland.

1) At the eastern boundary of the sheep zone in Queensland, black speargrass (Heteropogon contortus), which has a very sharp awned seed, is seen as the major problem. The change in pasture composition from kangaroo grass to black speargrass that occurred in the $1870 \mathrm{~s}$ and 80s in south-east Queensland (Shaw 1957, Deutscher 1959) is regarded as the driving variable in the transition from sheep to cattle in this region (Logan 1988). Diseases such as footrot and worms, and black speargrass are also likely to share a common climatic zone, i.e. coastal Queensland, amplifying the costs of management. Dingos are also a key limiting factor on the eastern boundary of the sheep industry in those areas where black speargrass is not a problem (D. Jordan, pers. comm.). Whilst factors such as pests, parasites and diseases can be controlled at a cost by husbandry and management, the possible expansion of black speargrass with wetter (Bisset 1962) and/or warmer conditions is an important issue at the eastern boundary. Thus development of a model to predict the distribution of black speargrass under climate change would enable impacts to be better assessed.

2) At the northern boundary the limiting factors are the high risk of floods, the unsuitability of tropical tall grass pastures, and the impact of high temperatures on reproduction and production. All these factors combine to make beef production a more economically attractive option (R. Armstrong, pers. comm.).

3) At the western boundary the severity of the environment in terms of variability and average pasture production results in low production per ha relative to costs and thus cattle enterprises are preferred (R. Armstrong, pers. comm.). Dingos are also an important factor influencing the westward distribution of sheep (L.R. Allen, pers. comm.).

The identification of climate-related constraints, and their continued monitoring on properties at the climatic boundaries would provide early warning of climate change impacts on woolbased grazing enterprises and the lagged effect on the spatial distribution of the industry.

\section{Approaches to modelling animal production}

Grazing enterprise models which simulate herd/flock dynamics and their associated financial performance generally require the user to input values of animal production (growth, reproduction, mortality), e.g. HerdEcon (Stafford Smith and Foran 1990) and Breedcow/Dynama (Holmes 1988). These types of models have been used to simulate: 1) impacts of climate variability on financial performance and stocking decisions (e.g. Gillard and Moneypenny 1990, Foran and Stafford Smith 1991, Stafford Smith and Foran 1992); 2) impacts of climate change and $\mathrm{CO}_{2}$ increase (Campbell et al. 1997); 3) decision rules for grazing management including use of seasonal climate forecasting (e.g. Stafford Smith et al. 1998); 4) changes in costs, prices, and markets (Holmes 1997); 5) property management and improvement options, e.g. pasture improvement (Wicksteed 1980, Gramshaw 1995, Mclvor 
and Moneypenny 1995); 6) government drought and taxation policy (White 1978, Stafford Smith and McKeon 1998); and 7) grazier-initiated model experiments (Buxton and Stafford Smith 1996).

Many of the above studies involved the use of grazier experience and expert opinion to nominate herd and flock attributes (LWG, wool growth, reproduction, mortality) for the range of climatic and management variables being simulated. Whilst this approach is likely to be most acceptable and accurate for the intended users of the simulation results (Buxton and Stafford Smith 1996), it does not necessarily allow extrapolation to other climatic patterns or locations.

Models currently available and which do simulate animal production can generally be divided into two groups: 1) dynamic, deterministic, mechanistic models (e.g. GRAZPLAN, Freer et al. 1997); or 2) dynamic, deterministic, empirical models (e.g. McCown 1980-81). Both model types are able to account for the variability and uncertainty associated with rainfall (Goodall 1969) by using historical climate data.

Empirical models are often more concerned with the quality of model output than the quality of the theory and are more likely to be used as Decision Support Systems (Denham and Spreen 1986). However, it has been argued that greater emphasis on developing a sound theoretical basis generally produces a more robust model that is better able to operate under conditions different from those in which it was developed. In such cases greater confidence would be derived from the use of mechanistic models in simulating the impact of variation or change in climate. We assess below the suitability of existing models for the purposes of climate change analyses for Queensland livestock.

The GrazFeed component of the GRAZPLAN software package (Freer et al. 1997) is based on the Feeding Standards for Australian Livestock: Ruminants (SCA 1990), and thus represents current physiological understanding of energy and protein systems for Australian ruminants. However, the model builders state that it is not suitable for application to grazing animals in "semi-arid rangelands of mainly shrub vegetation." Limited independent testing of GrazFeed with western Queensland sheep liveweight data using measured feed intake data (Hall 1996), and northern Australia sheep and cattle reproductive and mortality data (Moore et al. 1995) would support this statement. An early development of a physiologically-based model (White 1978) did not account for spatial variation in sheep production in north-west Queensland. Siebert and Hunter (1977) developed both mechanistic and empirical models of cattle LWG and suggested that their relationships could be "used in simulation studies of grazing systems without restriction." However, the short timeframe (three months) over which the LWG was predicted and the quality of the available pasture (dietary nitrogen range $15-23 \mathrm{~g} \mathrm{~N} / \mathrm{kg} \mathrm{OM}$ ) indicate that issues such as compensatory growth and the physiology of liveweight loss (Hogan 1996) were not addressed. Thus, as yet, a mechanistic model of animal production in northern Australia is not available.

As a result, development and application of annual wool and LWG (sheep and cattle) models for Queensland has relied on empirical simulation approaches. For example, simple plant growth indices have been used to determine the start and cessation of north Australian 'green' and 'dry' seasons (McCown 1980-81), and to quantitatively examine seasonal and annual cattle liveweight changes (Gillard 1979, McKeon et al. 1980, McCown et al. 1981, Jones et al. 1990, McCaskill 1991, McCaskill and McIvor 1993). Although diet models have been developed which account for a high proportion of seasonal variation in diet quality (Hendricksen et al. 1982, Hall 1996), simpler climate-derived indices have proved easier to implement when simulating cattle LWG over longer periods, i.e. 30 years (McKeon et al. 1986). McIvor and Moneypenny (1995) found that this approach could also be combined with stocking rate effects when expressed as percentage utilisation (intake $\div$ growth; McKeon and Rickert 1984, McKeon et al. 1990). 
For the wool industry, Hooper (1973) developed a regression model to predict wool cut per head for each State based on a 'seasonal conditions variable' and a trend in time. The seasonal conditions variable was developed from rainfall for selected months in wool producing districts. The regression explained $72 \%$ of the variation in Queensland's wool cut per head from 1960-61 to 1971-72. However, State-wide changes in numbers within different animal classes, e.g. number of lambs shorn, caused divergence in predicted and observed wool cut. No attempt was made to model regional variation in wool production.

Reid and Thomas (1973) showed that multiple regressions based on simulated monthly soil water explained more variation in regional wool production than rainfall for Queensland. Similarly, Flavel et al. (1987) found a broad based climatic measure of potential pasture growth (Fitzpatrick and Nix 1970) explained more of the variation in Australian average wool cuts than rainfall alone. More recently, Hall (1996) used multiple regressions based on simple climatic, soil water, pasture and dietary variables to account for a high proportion $\left(r^{2}=0.40\right.$ to 0.97 ) of the temporal and spatial variation in annual wool production and liveweight change from western Queensland sheep grazing trials.

The above discussion has focused on empirical models of wool production and LWG. However, to simulate grazing enterprises fully, models of rates of reproduction and mortality are also required. The effects of climate on reproduction and mortality have been modelled for sheep by White (1978) and cattle by Gillard and Moneypenny (1990). For cattle enterprises these relationships were derived from only one property in north-eastern Queensland but nevertheless have been used widely in subsequent studies (e.g. McIvor and Moneypenny 1995, Stafford Smith and McKeon 1998). This lack of extensive data and models of reproduction and mortality rates remains a major limitation to the simulation of climate effects on herd and flock dynamics across northern Australia. Other aspects of animal production which are currently not adequately addressed by models include: 1) diet selection and feed intake; 2) compensatory LWG; 3) the contribution of changes in rumen contents and other carcase attributes to modelling LWG; and 4) nutrient limitations (e.g. phosphorus).

Grazing trials have been a key experimental tool used by researchers to measure animal production. However, a recent review (Ash and Stafford Smith 1996) of stocking rate trials in rangelands has questioned the extent to which data collected on small paddocks with a limited number of animals can be applied to 'real' paddocks or properties. A.J. Ash (pers. comm.), in a further review of rangeland trials, found that the slope of the relationship between LWG and stocking rate was flatter than has been derived from grazing trials conducted at a smaller scale (e.g. McKeon and Rickert 1984) suggesting that the extrapolation of relationships derived from grazing trials with small paddocks to property data may be problematic under some circumstances.

Hall (1996) examined to what extent wool production models derived from small-scale sheep grazing trials could explain year-to-year variation in Queensland shire level wool production data reported by the Australian Bureau of Statistics (ABS). Annual variation in shire fleece weight $(\approx 10 \% \mathrm{CV})$ was lower than measured at the small paddock or grazing trial scale $(\approx 19.5 \% \mathrm{CV})$. Not unexpectedly, models derived from grazing trial data explained a lower proportion of the annual variability of shire data $(<49 \%)$. Nevertheless, Hall (1996) was able to produce a model of Queensland's wool production accounting for $78 \%$ of year-to-year variation using these relationships and the Aussie GRASS spatial pasture growth model of Queensland (Carter et al. 1998). The analysis by Hall (1996) suggests that property and regional statistics can be used to construct empirical models that represent adequately the effect of climate variation and are compatible with smaller scale grazing trials.

\section{Case studies of models of climate change impacts on beef cattle production}

To examine the sensitivity of grazing industries to climate change, we conducted the following three case studies applying empirical models to account for the effects of climatic variation: 
1) beef cattle liveweight gain in the Queensland black speargrass zone;

2) calculation of regional 'safe' carrying capacity; and

3) Queensland State-wide 'safe' carrying capacity.

\section{Climate change scenario and representation}

As examples of climate change scenarios we chose a doubling of $\mathrm{CO}_{2}$ accompanied by a $3^{\circ} \mathrm{C}$ increase in temperature and rainfall changes of $\pm 10 \%$ (CIG 1996). The impact of these changes on Queensland's native pastures was simulated using the pasture growth model GRASP (McKeon et al. 1990, Littleboy and McKeon 1997) which has been extensively calibrated and validated in Queensland (Carter et al. 1996b, Hall 1996, Day et al. 1997a).

The modification of GRASP to include $\mathrm{CO}_{2}$ effects has been described in detail by Howden et al. $(1998 \mathrm{a}, \mathrm{b})$. Preliminary glasshouse experiments had been conducted on the effects of $\mathrm{CO}_{2}$ increase on the native tropical grasses black speargrass and kangaroo grass (Themeda triandra, L. Walker, pers. comm.). These effects have been combined with other available data to represent the general effects of doubling atmospheric $\mathrm{CO}_{2}$ levels on the following characteristics of $\mathrm{C}_{4}$ pasture growth (Howden et al. 1998a, b):

1) potential regrowth rate $(\mathrm{kg} \mathrm{DM} / \mathrm{ha} / \mathrm{day},+10 \%)$;

2) transpiration efficiency ( $\mathrm{kg} \mathrm{DM} / \mathrm{ha} / \mathrm{mm} @ 20 \mathrm{hPa},+40 \%)$;

3) green yield at which potential transpiration is $50 \%$ of potential evapotranspiration (kg DM/ha, $+40 \%$ );

4) rate of nitrogen uptake ( $\mathrm{kg} \mathrm{N} / \mathrm{ha}$ per $100 \mathrm{~mm}$ transpiration, $+20 \%)$; and

5) radiation use efficiency $\left(\mathrm{kg} / \mathrm{ha}\right.$ per $\left.\mathrm{MJ} / \mathrm{m}^{2},+5 \%\right)$.

The change in temperature was represented by simply adding $3^{\circ} \mathrm{C}$ to daily minimum and maximum temperatures and dew point in the control daily climate file. Vapour pressure deficit and Class A pan evaporation were then calculated. Rainfall decrease and increase were represented by multiplying the rainfall for each day in the control file by 0.9 and 1.1 respectively. No adjustments were made to daily solar radiation.

McKeon et al. (1998b) have compared the above simplistic approach to representing a climate change scenario with the more sophisticated but expensive method of using daily climate simulated by weather-generators linked to the output of General Circulation Models (Bates et al. 1996). These different approaches to representing the same climate change scenario (including baseline climate) resulted in differences of $\pm 9 \%$ across locations in important variables such as annual pasture growth index and $\pm 5 \%$ in length of the growing season, i.e. the percentage of days in which the growth index exceeded 0.05 . Thus simulated climate change impacts of less than $10 \%$ at a particular location are of the same order as variation due to different representations of climate or climate change. However, when the impacts were averaged across locations there was little difference $(<4 \%)$ due to type of representation.

For the climate change case studies, the climate for the period 1961 to 1990 was used as the control and the control $\mathrm{CO}_{2}$ level was taken as $350 \mathrm{ppm}$. Thus the experimental design for the sensitivity tests was a $2 * 2 * 3$ factorial design:

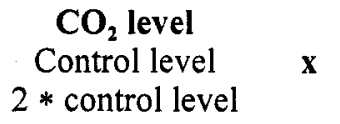

Temperature

Control temperatures

Control temperatures $+3^{\circ} \mathrm{C}$

\author{
Rainfall \\ x $\quad 90 \%$ of control rainfall \\ Control rainfall \\ $110 \%$ of control rainfall
}

As pasture management affects pasture growth and other simulated variables, recommended management guidelines regarding stocking rate and burning were adopted for the following simulation case studies: 
1. stock numbers were adjusted each year at the end of the growing season ( $1^{\text {st }}$ June) to eat $30 \%$ of available pasture over the next 12 months (Beale et al. 1986, Orr 1986, Partridge 1992, 1993); and

2. $33 \%$ of grazing area was burnt each October if pasture yield exceeded $1200 \mathrm{~kg} \mathrm{DM} / \mathrm{ha}$ (Partridge 1992, 1993).

These tactical rules resulted in a plausible management adaptation to climate change and variation.

Management options (frequency of burning, clearing and regrowth control) are likely to have large effects on tree density (Burrows 1995, Moore et al. 1997) and the application of these management options is strongly influenced by pasture growth through fuel loads and perceived economic advantage of reducing woody plant density. However, the effective tree density, i.e. the competitiveness of trees for water and nitrogen was assumed not to change in response to changes in rainfall, temperature and $\mathrm{CO}_{2}$ in order to reduce the complexity of the sensitivity study.

Pasture growth parameters for the GRASP model have been previously summarised across all sites (>160 site * year combinations) for which the model had been calibrated and validated (Day et al. 1997a). The major parameters in which individual sites differed from the summary parameters were: 1) potential nitrogen uptake $(8-25 \mathrm{~kg} / \mathrm{ha} / \mathrm{year})$; and 2) the critical nitrogen content of pasture at which growth stops $(0.4$ to $1.2 \%)$. These parameters are affected by species composition, previous grazing history and phenological development. Models of the effects of climate variation on these factors are yet to be developed and hence for the purpose of sensitivity studies, summary parameters for potential nitrogen uptake $(20 \mathrm{~kg} / \mathrm{ha} / \mathrm{year})$ and critical nitrogen content $(0.68 \%)$ have been used. The major implication of these assumptions is that in favourable environments, simulated growth is limited by nitrogen in most years and therefore not likely to be as responsive to changes in climate and $\mathrm{CO}_{2}$ which increase potential plant growth.

Case study I: Climate change impacts on cattle liveweight gain in the Queensland black speargrass zone

The black speargrass zone of Queensland occupies approximately 23 million ha of the coastal foothills of Queensland and carries 3.3 million (25-30\%) of the State's beef cattle (Tothill and Gillies 1992). As stated previously, several empirical models using simulated growth indices have been developed to include the effects of year-to-year variation in climate and stocking rate on seasonal and annual cattle liveweight gain and hence in the following model we have developed this approach further.

To develop the model, data were used from three grazing trials that covered a range of locations in the coastal black speargrass zone (southern, central, northern) and management options (stocking rate, phosphorus application, pasture burning). Detailed descriptions of the trials are given in Day et al. (1997a) and only a brief description is given here.

1. Southern zone - Mt Bambling paddock ( 30 ha, at Brian Pastures, R. Roberton unpublished data): a single native pasture paddock was grazed by three age-groups of steers from 1979 to 1994 , providing 16 years of seasonal and annual steer liveweight data. These years covered a wide range of climatic conditions, e.g. 1982 - severe drought, 1983 - warm wet winter. One limitation with these data has been the inevitable change over time in the genotype of animals used. However, the rigorous control of pasture management (annual burning when possible and constant stocking rate), frequent weighings, and constant annual replacement dates has ensured a high quality data set for examining climatic effects. 
2. Central zone - Galloway Plains (Burrows 1997): the major experimental treatments were five stocking rates on native pasture. Other treatments included supplements, burning and oversowing with pasture legumes. Only the stocking rate - native pasture treatments (from the western block) were used in the following analysis.

3. Northern zone - Kangaroo Hills (Gillard 1979): the treatments were cleared and uncleared native pasture grazed at two stocking rates and two fertiliser (phosphorus) treatments. All native pasture paddocks were oversown with the pasture legume Townsville stylo (Stylosanthes humilis) which did not contribute greatly to pasture yield (Gillard 1979).

The soil water-pasture growth model GRASP was calibrated for each site using either exclosure yield data or grazed pasture yields measured in seasons following burning (Day et al. 1997a). The model was then used to simulate variables such as seasonal/annual pasture growth, percent utilisation (intake $\div$ growth) and relevant indices, e.g. pasture growth index (Fitzpatrick and Nix 1970) and percentage of days when the growth index exceeded 0.05 (after McCaskill 1991).

Analysis of LWG measured over seasonal periods (one to six months) resulted in regression models that explained a high proportion of seasonal LWG $\left(\mathrm{r}^{2}>0.70\right)$ but overestimated annual LWG (McKeon et al. 1998a). Factors such as compensatory gain, changes in rumen content and changing energy value of gain were likely to be the cause of this overestimation. As a result, further analysis concentrated on the development of annual models of LWG.

For the three locations in the black speargrass zone the general model for annual steer LWG $(\mathrm{kg} / \mathrm{head} /$ day) was (Fig. 1a):

$$
\begin{aligned}
& L W G=0.060+0.00483 * \% \text { gidays }-0.00206 * \% \text { utilisation } \\
& \qquad\left(\mathrm{r}^{2}=0.709, \mathrm{P}<0.001, \mathrm{n}=76, \text { eq. } 1\right)
\end{aligned}
$$

where \% gidays was the percentage of days in the year when the growth index $>0.05$; and $\%$ utilisation was intake $\div$ growth for the annual period July to June expressed as a percentage.

A wide range of values of \% gidays and \% utilisation was covered (Figs $1 \mathrm{~b}$, c) suggesting that the model can be used over a wide range of climatic variability in the black speargrass zone. However, the model does not explicitly account for the impacts of phosphorus and other factors on animal production. This form of model was similar to that developed by McIvor and Moneypenny (1995) for a range of pasture options at Charters Towers. The above equation has been modified (McKeon et al. 1998a) to include the effects of pasture burning $(+15 \mathrm{~kg}$ LWG/head/year) and periods when pasture feed deficits are likely to limit intake and cause weight loss (e.g. when pasture dry matter is less than $300 \mathrm{~kg} / \mathrm{ha}$ ).

The data used in developing the above model included a large number of possible sources of variation between years and trials, e.g. paddock variability in soils, pastures and tree density, animal genotype, previous animal history, errors in measuring liveweight, sub-clinical diseases (e.g. three day sickness), and possible weather effects on grazing and diet such as prolonged wet weather. The robustness of the derived relationship across locations and years provides some confidence in representing climate and stocking rate effects.

\section{Simulation results: case study 1}

Pastures with low tree densities were simulated with tree basal areas of 1,1 and $4 \mathrm{~m}^{2} / \mathrm{ha}$ for Gayndah, Galloway Plains and Charters Towers respectively representing southern, central and northern black speargrass zones of Queensland. The lower tree density of the southern and central black speargrass zones reflects the fact that areas within these zones have been previously cleared. The greater tree density and seasonal rainfall distribution at Charters Towers resulted in approximately half the pasture growth simulated at other locations (Table 1). 


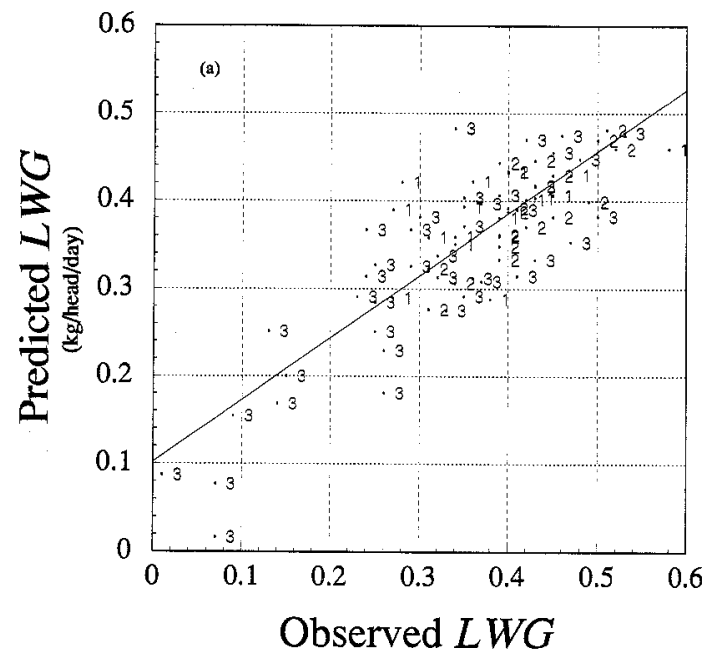

(kg/head/day)

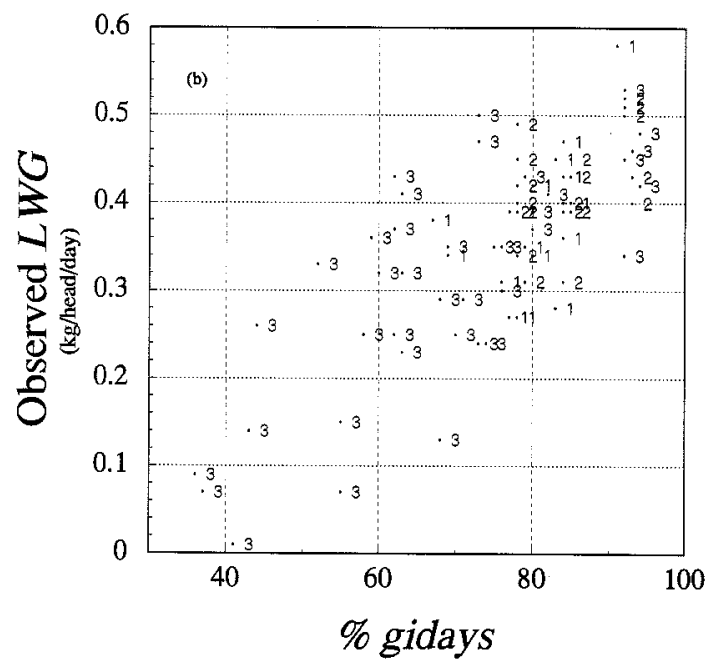

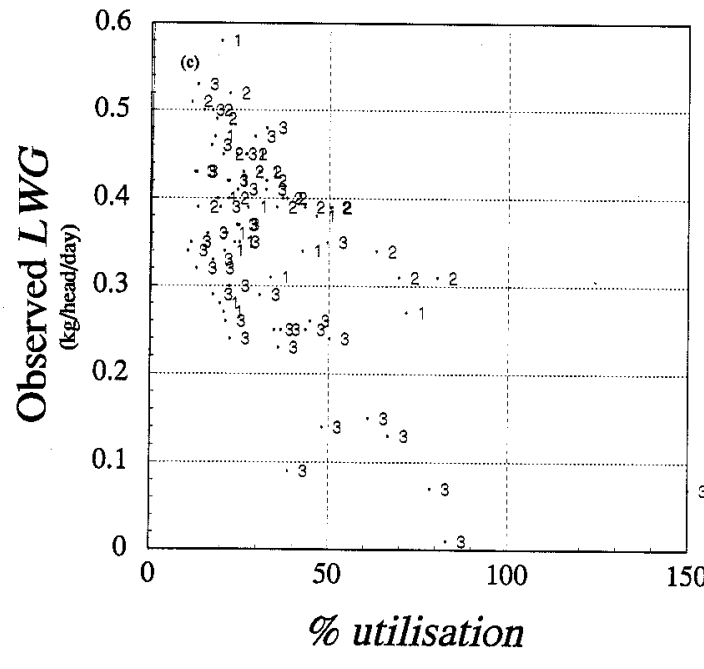

Fig. 1.(a) Observed and predicted LWG per head for Brian Pastures (1), Galloway Plains (2) and Kangaroo Hills (3) using equation 1. (b) Relationship between \% gidays estimated from GRASP and LWG per head for data from Brian Pastures (1), Galloway Plains (2) and Kangaroo Hills (3). (c) Relationship between $\%$ utilisation estimated from GRASP and LWG per head for data from Brian Pastures (1), Galloway Plains (2) and Kangaroo Hills (3). 


\begin{tabular}{|c|c|c|c|c|c|c|c|c|c|c|c|c|}
\hline 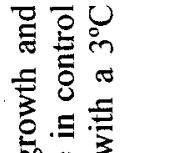 & 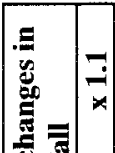 & $\because$ & 9 & & & 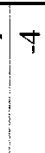 & & & & & & $a$ \\
\hline 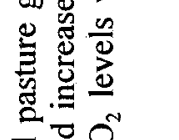 & 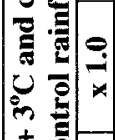 & 9 & $\sigma$ & $m-$ & יז'ד & $\infty$ & $\simeq$ & $\infty$ & $\nabla$ & & & $m$ \\
\hline 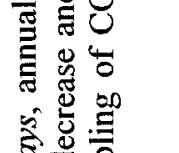 & 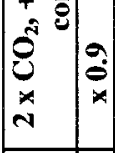 & $=$ & - & 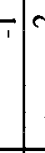 & & $\frac{n}{1}$ & 0 & 0 & $?$ & $\sigma$ & $n$ & $\approx$ \\
\hline 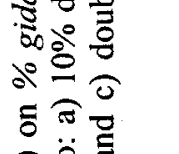 & 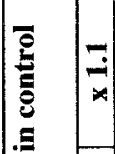 & \pm & 익 & +0 & & $N_{1}$ & 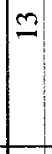 & a) & 0 & $m$ & $\infty$ & $\nabla$ \\
\hline 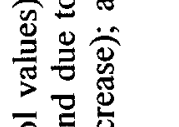 & 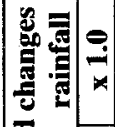 & $\simeq$ & $\infty$ & -10 & 07 & 49 & 10 & $r$ & 이 & $\Theta$ & $n$ & $i$ \\
\hline 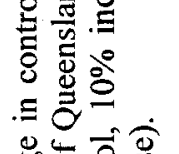 & 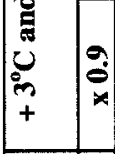 & & 0. & $?$ & $T r$ & 8 & 0 & $n$ & Y & $\theta$ & - & 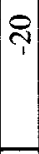 \\
\hline 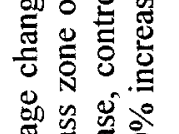 & 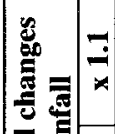 & $N$ & -4 & $n$ & 010 & 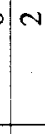 & $N$ & - & a) & in & - & 유 \\
\hline 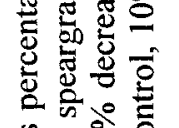 & 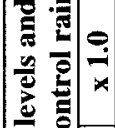 & - & 010 & $N$ & 10 & $\uparrow$ & $1-$ & 0 & $m$ & $m$ & $\nabla$ & In \\
\hline 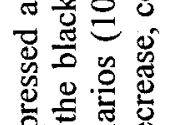 & $\underset{\sim}{\tilde{N}} \cdot \vec{a}$ & $\Upsilon$ & $T o$ & ד & r & 7 & N & $\uparrow$ & $\nabla$ & 0 & ol & $\infty$ \\
\hline 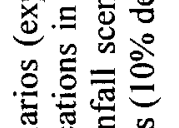 & : & & -0 & $m-$ & -- & 10 & $N$ & $N$ & 0 & & $m$ & $m$ \\
\hline 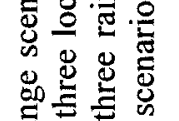 & 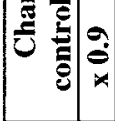 & $?$ & 1 & 寸 & 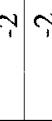 & $\infty$ & $r$ & $\Upsilon$ & T. & $?$ & স & $\frac{m}{7}$ \\
\hline 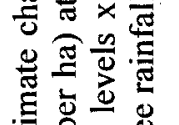 & $\bar{E}$ & $\infty$ & $\infty$ & ชै & $\frac{n}{n}$ & 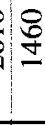 & $\stackrel{\infty}{2}$ & g) & $\Xi$ & & $\approx$ & \pm \\
\hline 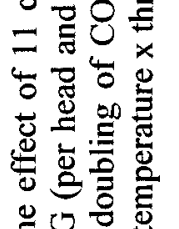 & 莺 & : & 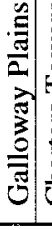 & | & 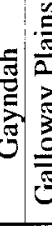 & 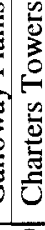 & 3. & 先 & 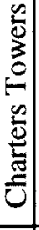 & & 资 & 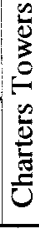 \\
\hline 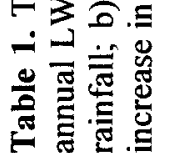 & $\begin{array}{l}\frac{0}{2} \\
\frac{\pi}{2} \\
\frac{\pi}{2}\end{array}$ & & 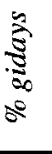 & & & & & $\underbrace{\stackrel{80}{*}}_{0}$ & & & & \\
\hline
\end{tabular}


Simulation results for black speargrass pasture growth at Gayndah and Galloway Plains were limited in most years by nitrogen availability, hence changes in rainfall, $\mathrm{CO}_{2}$, and temperature had little impact $(-3$ to $+1 \%$, Table 1$)$. However, at Charters Towers, moisture was limiting in many years and hence the impact of the changes in rainfall, $\mathrm{CO}_{2}$, and temperature on pasture growth were greater $(-20$ to $+6 \%)$. The main effect of increased $\mathrm{CO}_{2}$ was to slightly buffer the negative effects of reduced rainfall and higher temperature (Table 1). The simulation results suggest that the presence of trees competing for water and nutrients caused small but complex interactions with the above factors highlighting the overall complexity of native pasture grazing systems.

The adaptive grazing management system used in the simulation resulted in similar levels of pasture utilisation ( 24 to $28 \%$ ) across all treatments and hence LWG per head was dominated by changes in \% gidays (Table 1 ). The \% gidays variable was relatively insensitive to rainfall changes because the seasonal distribution of rainfall was not altered in the climate change scenarios used here. At Gayndah and Galloway Plains warmer temperatures resulted in higher $\%$ gidoys and increased LWG per ha (5 to $15 \%$ ) across the range of rainfall scenarios under doubled $\mathrm{CO}_{2}$ (Table 1). Even the warmer-drier scenario had increased LWG per ha for Gayndah (9\%) and Galloway Plains (5\%). However at Charters Towers, increased temperature did not change the effect of the rainfall scenarios on \% gidays and LWG per head, but exacerbated the negative effects of reduced rainfall on pasture growth and LWG per ha. Doubling $\mathrm{CO}_{2}$ reduced the negative effects of lower rainfall and increased temperature (Table 1).

Across the three locations the combined effects of changes in rainfall, temperature and $\mathrm{CO}_{2}$ resulted in -15 to $+15 \%$ changes in $L W G$ per ha indicating that $\pm 10 \%$ rainfall change scenarios could be amplified in terms of cattle production depending on location. The sensitivity study highlighted the complexity of the grazing system and the different effects that can occur even within the same pasture community.

\section{Case study 2: Climate change impacts on Queensland regional 'safe' carrying capacity}

The high year-to-year variability in climate and pasture production of Queensland's and Australia's grazing lands has long been recognised as a major source of risk in terms of herd/flock management, financial performance and resource degradation (White 1978, Gardener et al. 1990, Stafford Smith and Foran 1992, Tothill and Gillies 1992).

Some graziers have effectively managed these risks by adopting conservative or 'safe' stocking rates or by managing around a 'safe' carrying capacity (Johnston et al. 1.996a). The demonstrable evidence that these stocking rates are 'safe' is provided by the long-term survival of these enterprises and the subjective assessment of property condition relative to more degraded properties (Johnston et al. 1996a, b).

The adoption of 'safe' stocking rates is likely to result in a range of synergistic benefits which are difficult to separate including increased individual animal production, higher reproductive and lower mortality rates, better soil conditions in terms of infiltration and organic matter, more opportunities for pasture burning to control woody weeds, higher proportion of desirable perennial grasses and less impact of rainfall deficits (drought) on pasture feed availability (Day et al. 1997a).

The objective calculation of 'safe' stocking rate or carrying capacity has been a major theme of recent work (Scanlan et al. 1994, Johnston et al. 1996a, b). This follows the pioneering work of Condon (1968) and Condon et al. (1969) who developed quantitative systems for calculating 'safe' carrying capacities for both western NSW and central Australia (NT) respectively. The fundamental component of the method was the relationship between average rainfall and the carrying capacities estimated from regional ratings or benchmark properties. In 
this way, both successful community experience and climatic and ecological knowledge were combined. The system also included the effects of varying tree density, land systems and resource condition.

This approach has been modified in Queensland by formally simulating these biophysical effects on average pasture growth (Scanlan et al. 1994, Johnston et al. 1996a, b, Day et al. 1997b) with equations developed from the GRASP model. For three regions of Queensland (south-west, south-east, north-east), similar relationships exist between 'safe' carrying capacity and average annual pasture growth. In these case studies, 'safe' carrying capacity was estimated by graziers for the different land systems within their properties (Fig. 2). Analysis of the pooled data from these regions showed that pasture growth accounted for $77 \%$ of the variation in carrying capacity across a wide range of soil types, land systems, pasture communities, grazing enterprises and climatic zones. When estimates of 'safe' carrying capacity were expressed as the ratio of animal intake per ha to average annual pasture growth, i.e. pasture utilisation, $47 \%$ of estimated 'safe' carrying capacities fell between 15 and $25 \%$ pasture utilisation with $72 \%$ of estimated 'safe' carrying capacities being equivalent to less than $25 \%$ utilisation of average annual pasture growth (Fig. 3).

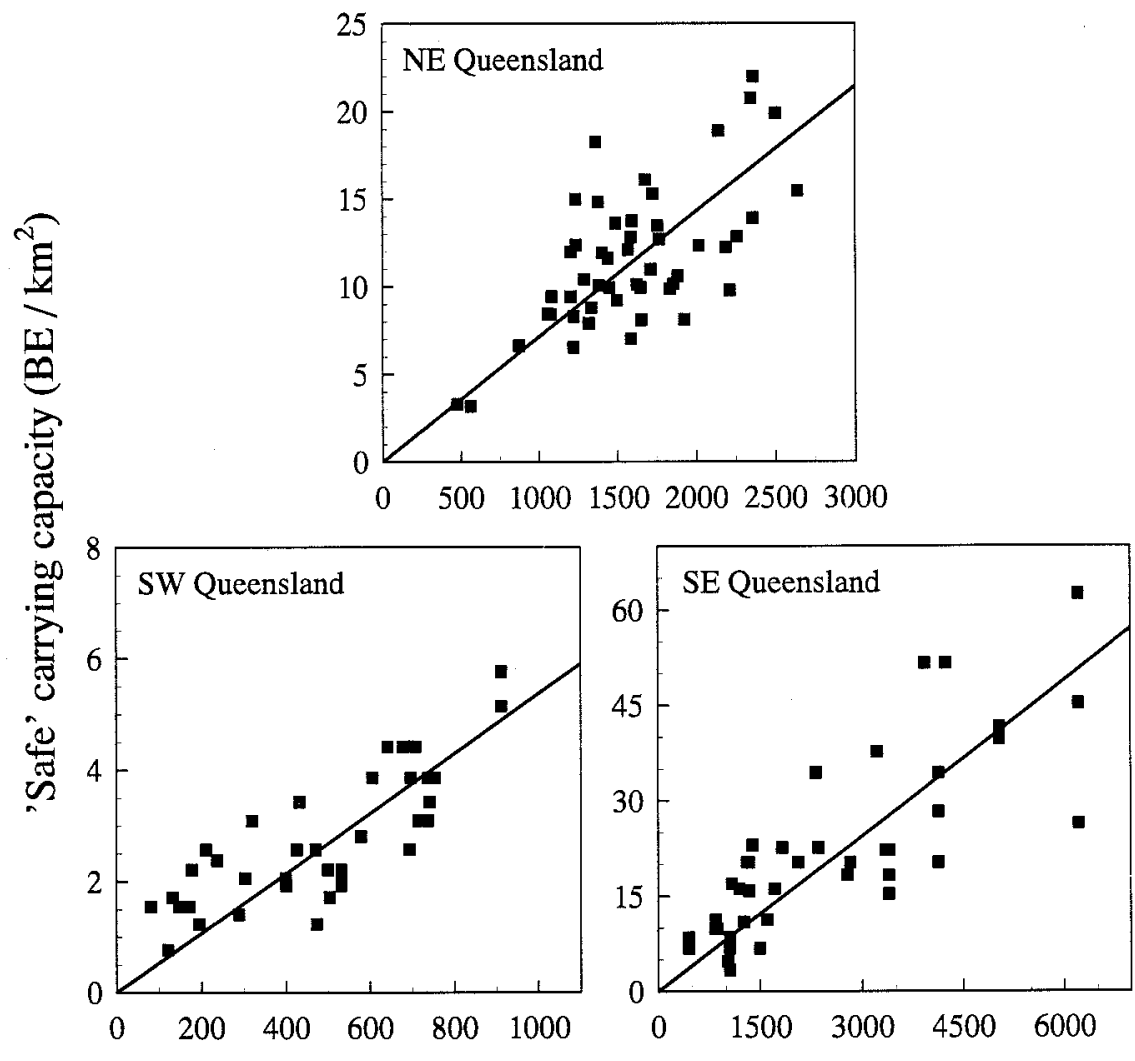

Simulated average annual pasture growth ( $\mathrm{kg} \mathrm{DM} / \mathrm{ha})$

Fig. 2. Relationships between estimated 'safe' carrying capacity for properties and land systems in three regions of Queensland: north-east Queensland (Scanlan et al. 1994); south-west Queensland (Johnston et al. 1996a); and south-east Queensland (Day et al. 1997b).

For each region, the regression of pasture growth and dry matter intake was used to calculate their 'safe' utilisation rates: south-west Queensland, 14.5\%; north-east Queensland, 19.3\%; and south-east Queensland, $22.0 \%$. This low variation in 'safe' utilisation across the three regions is surprising given that they differ substantially in: 1) year-to-year variability in rainfall; 
2) disappearance rates of dry matter; 3 ) nitrogen dilution by plants; 4) frequency of burning to control woody plants and improve animal nutrition; 5) animal type (sheep versus cattle); and 6) number of potential growth days (i.e. \% gidays, Table 2).

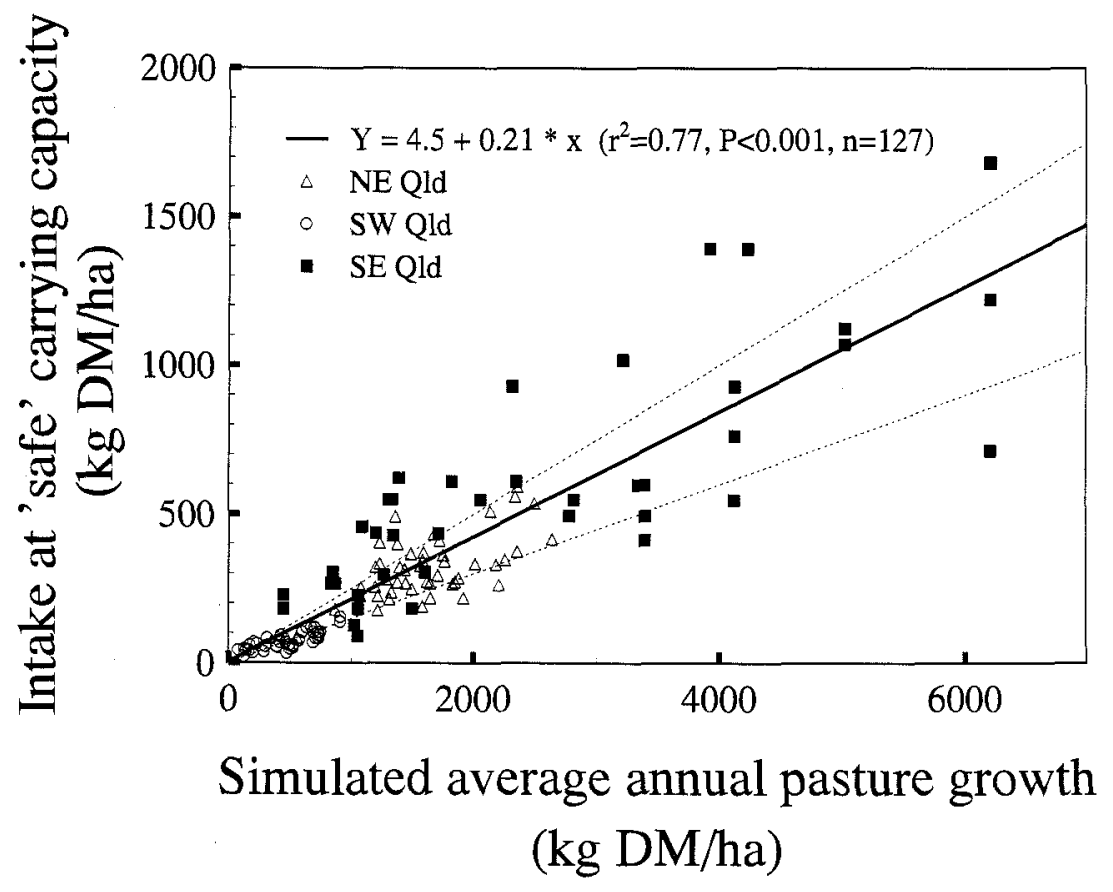

Fig. 3. Intake at 'safe' carrying capacity for three regions in Queensland covering a range of annual pasture growth rates (data from Scanlan et al. 1994, Johnston et al. 1996a, Day et al. 1997b). The lower and upper dashed lines represent utilisation rates of 15 and $25 \%$ respectively.

To some extent these differences compensate for each other. For example, in the drier southwest region the higher temporal variation in plant growth is buffered by lower disappearance rates, higher nutrient content of dead plant material and low utilisation rates. The low utilisation rates in the more climatically benign eastern environments provide more opportunities for pasture burning and hence benefits in animal nutrition and pasture management. The combination of these extensive analyses with simple subjective judgements at other locations (Table 2) indicates that 'safe' carrying capacity is correlated with \% gidays $(\mathrm{P}<0.05)$. The central Australia location, an ephemeral pasture community with a winter growth component, had a relatively high utilisation rate probably reflecting the higher quality of animal nutrition provided by ephemeral forbs in this environment (Squires and Siebert 1983). For the six remaining native perennial grass communities the 'safe' utilisation rate derived from property level data and expert opinion (\% SU propery, Table 3$)$ was highly correlated with \% gidays:

$$
\begin{aligned}
& \% S U_{\text {propery }}=-11.2+0.385 * \% \text { gidays } \\
& \qquad\left(\mathrm{r}^{2}=0.853, \mathrm{P}<0.01, \mathrm{n}=6, \text { eq. } 2\right)
\end{aligned}
$$

'Safe' carrying capacity estimates were also available for 46 pasture communities in Queensland (Tothill and Gillies 1992). These estimates for pastures in good condition were based on values reported in the literature and checked with local expert resource groups. For the purpose of comparison with producer survey data (O'Rourke et al. 1992) we have aggregated the estimates of Tothill and Gillies (1992) to the 12 regions in Queensland (Table 3 ). Average pasture growth for each region was calculated by two approaches: 
1) the Aussie GRASS spatial pasture growth model of Carter et al. (1998) was run on a $5 \mathrm{~km}$ grid and aggregated to the above 12 regions; and

2) the pasture model GRASP, as described in the previous case study, was run for one climate station (point) in each region for both treed and cleared pastures using summary pasture parameters. Tree densities and area of cleared pastures (Table 3) were derived from the data sets used in the Aussie GRASS spatial model (Carter et al. 1996a) and were used to calculate an average annual pasture growth. Locations were chosen to reflect the rainfall reported by graziers in the north Australia beef producer survey (O'Rourke et al. 1992).

Table 2. Estimated 'safe' carrying capacity in beef equivalents (BE) and associated variables for seven locations/regions in northern Australia.

\begin{tabular}{|c|c|c|c|c|c|}
\hline Location & Source & $\begin{array}{c}\text { 'Safe' } \\
\text { carrying } \\
\text { capacity } \\
\left(\mathrm{BE} / \mathrm{km}^{2}\right)\end{array}$ & $\begin{array}{c}\text { Annual } \\
\text { pasture } \\
\text { growth }^{1} \\
\text { (kg DM/ha) }\end{array}$ & $\begin{array}{c}\% \text { 'safe' } \\
\text { utilisation }^{2} \\
\left(\% S U_{\text {property }}\right)\end{array}$ & $\begin{array}{c}\% \\
\text { gidays }^{3}\end{array}$ \\
\hline $\begin{array}{l}\text { Kidman } \\
\text { Springs, N.T. }\end{array}$ & $\begin{array}{l}\text { R. Dyer pers. } \\
\text { comm. }\end{array}$ & 8.5 & 2400 & 9.5 & 63 \\
\hline $\begin{array}{l}\text { Alice Springs, } \\
\text { N.T. }\end{array}$ & $\begin{array}{l}\text { M Stafford } \\
\text { Smith pers. } \\
\text { comm. }\end{array}$ & 3.0 & 560 & 14.5 & $\overline{42}$ \\
\hline $\begin{array}{l}\text { Julia Creek, } \\
\text { N.W. Qld. }\end{array}$ & Day et al. $1997 \mathrm{a}$ & 6.4 & 1600 & 12.7 & 55 \\
\hline $\begin{array}{l}\text { Galloway } \\
\text { Plains, coastal } \\
\text { central Qld. }\end{array}$ & $\begin{array}{l}\text { R. Hendricksen } \\
\text { pers. comm. }\end{array}$ & 25.0 & 2880 & 23.4 & 88 \\
\hline South-west Qld & $\begin{array}{l}\text { Johnston et al. } \\
1996 \mathrm{a}, \mathrm{b}\end{array}$ & 2.7 & 480 & 14.5 & 67 \\
\hline North-east Qld & $\begin{array}{l}\text { Scanlan et al. } \\
1994\end{array}$ & 11.6 & 1600 & 19.3 & 81 \\
\hline South-east Qld & Day et al. $1997 \mathrm{~b}$ & 22.1 & 2500 & 22.0 & 83 \\
\hline
\end{tabular}

${ }^{1}$ average annual pasture growth was calculated using the GRASP model calibrated to exclosure pasture measurements.

$2 \%$ 'safe' utilisation was calculated assuming dry matter intake of $2700 \mathrm{~kg} / \mathrm{year} / \mathrm{BE}$ divided by average annual pasture growth.

$3 \%$ gidays was the average percentage of days in each year that the simulated growth index exceeded 0.05 (after McCaskill 1991).

Pasture growth from the point and spatial models for the 12 locations/regions were highly correlated $\left(r^{2}=0.79, n=12, P<0.001\right)$ with the 'southern rolling downs' being the major outlier (Table 3). Whilst the location representing this region (Roma) was chosen to match reported rainfall by beef producers, the region includes much of the wool industry in the southern drier areas. The beef producer survey is thus likely to be geographically biased to wetter parts of the region. Hence the point model is not regarded as being inaccurate relative to the beef producer areas and was therefore considered suitable for this sensitivity study.

'Safe' annual utilisation rates were calculated from the recommended carrying capacities of Tothill and Gillies (1992) and the two estimates of average annual pasture growth. In both cases 'safe' utilisation was strongly correlated with \% gidays (Fig. 4): 


$$
\begin{aligned}
& \% S U_{\text {poimt }}=-36.96+0.782 * \begin{array}{l}
\% \text { gidays } \\
\\
\left(\mathrm{r}^{2}=0.87, \mathrm{n}=12, \mathrm{P}<0.001, \text { eq. } 3\right)
\end{array} \\
& \% S U_{\text {spatial }}=-26.51+0.625 * \begin{array}{l}
\% \text { gidays } \\
\left(\mathrm{r}^{2}=0.91, \mathrm{n}=12, \mathrm{P}<0.001, \text { eq. } 4\right)
\end{array}
\end{aligned}
$$

Where $\% S U_{\text {poim }}$ was the 'safe' annual utilisation rate for a specific location/region calculated using pasture growth from the GRASP model; $\% S U_{\text {spatial }}$ was the 'safe' annual utilisation rate for a specific location/region calculated using pasture growth from the Aussie GRASS spatial model; and \%gidays was the percentage of days the growth index $>0.05$ as calculated using the GRASP model.
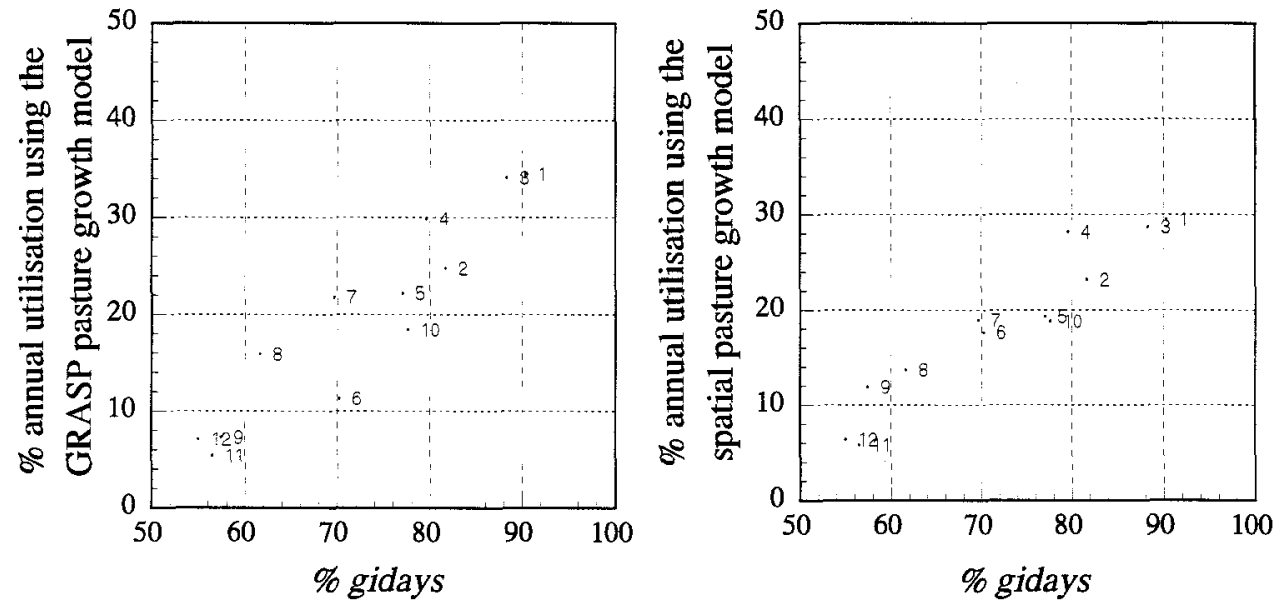

Fig. 4. Relationships between annual pasture utilisation and \% gidays. Pasture utilisations were calculated using the carrying capacity estimates of Tothill and Gillies (1992) and pasture growth data for each region simulated using a) selected climate stations and the GRASP pasture growth model, and b) the Aussie GRASS spatial pasture growth model of Carter et al. (1998). Regions are: 1 - High rainfall; 2 - Brigalow; 3 - Southern speargrass; 4 - Queensland bluegrass; 5 - Southern Aristida; 6 - Southern Downs; 7 - Central and northern Downs; 8 Mulga lands; 9 - Queensland spinifex; 10 - Northern speargrass; 11 - Northern Aristida; and 12 - Gulf-Peninsula.

We examined the correlation of $\% S U_{p o i m}$ with a range of other variables including animal production and pasture attributes and year-to-year variability of climate as measured by the coefficient of variation $(\mathrm{CV})$. As might be expected $\% S U_{\text {poim }}$ was significantly $(\mathrm{P}<0.05)$ negatively correlated with the CVs for rainfall $\left(r^{2}=0.49\right)$ and \%gidays $\left(r^{2}=0.42\right)$ but not pasture growth $\left(\mathrm{r}^{2}=0.21\right)$. However, positive correlations (with $\% S U_{p o i m}$ ) of similar strength occurred with animal production and soil attributes (\% branding $\mathrm{r}^{2}=0.40, \mathrm{P}<0.05$; estimated LWG per head $r^{2}=0.36, P<0.05$; soil phosphorus $\left.r^{2}=0.64, P<0.01\right)$. Similarly, $\% S U_{\text {poimt }}$ was negatively correlated with graziers use of urea supplements $\left(\mathrm{r}^{2}=0.47, \mathrm{P}<0.05\right)$. Pasture attributes related to length of the growing season such as average NDVI and tree density (Specht and Specht 1995) were positively correlated $\left(\mathrm{r}^{2}=0.42\right.$ and 0.53 respectively, $\left.\mathrm{P}<0.05\right)$ with $\% S U_{\text {poin }}$. Attributes related to pasture condition (percentage of properties with buffel grass spreading, percentage of area in deteriorated or degraded condition) had low non-significant correlations ( $\mathrm{r}^{2}$ less than $0.18, \mathrm{P}>0.05)$ with $\% S U_{\text {poim }}$. Thus the correlation with $\%$ gidoys $\left(r^{2}=0.91\right.$, equation 4$)$ was substantially higher than any other attribute. The correlation with animal and plant attributes support the hypothesis that the 'safe' utilisation of native pasture from both ecological and nutritional viewpoints is related to the measure of animal nutrition (\% gidoys) across regions. 
At a finer scale within a region, e.g. south-west Queensland, climatic indices are similar and 'safe' utilisation rates were found to be related to nutrient availability (Johnston et al. 1996a) further supporting the above hypothesis.

The above equations (2, 3 and 4) derived from two independent approaches, i.e. property/expert opinion and Tothill and Gillies (1992) data, provide the basis for calculating the 'safe' carrying capacity for the 12 regions in Queensland and their sensitivity to climate change scenarios. The same approach adopted in Case study 1 was used to simulate average pasture growth and \% gidays. As before, tree density was held constant for the purpose of the sensitivity experiment.

For the purposes of this case study, 'safe' carrying capacity for each region was calculated using 'safe' utilisation rates based on equation 2 derived from property data and expert opinion $\left(\% S U_{\text {property }}\right)$ :

$$
\text { Safe } C C=\frac{\% S U_{\text {property }}}{100} * \frac{\text { pasture growth }}{\text { feed intake }}
$$

where Safe CC was the 'safe' carrying capacity of each region expressed in $400 \mathrm{~kg}$ beast equivalents $(\mathrm{BE}) / \mathrm{ha}$; $\% S U_{\text {property }}$ was the 'safe' utilisation rate from equation 2 ; pasture growth was average annual pasture growth ( $\mathrm{kg} \mathrm{DM} / \mathrm{ha})$; and feed intake was the annual feed intake for a $400 \mathrm{~kg} \mathrm{BE}$ and estimated to be $2700 \mathrm{~kg}$ DM. (A BE consumes $\approx 10 \mathrm{~kg} \mathrm{DM} /$ day for six months of the growing season and $\approx 5 \mathrm{~kg} D M /$ day for six months of the dormant period, SCA 1990).

Equation 5 suggests that climate change effects on 'safe' carrying capacity can be amplified where changes in average annual pasture growth and \% gidays occur in the same direction. In Case study 3 we also examine 'safe' carrying capacities calculated using 'safe' utilisation rates from equation $3\left(\% S U_{\text {poim }}\right)$ derived from the work of Tothill and Gillies (1992).

\section{Simulation results: Case study 2}

There was considerable interaction between location and the impact of changes in rainfall, $\mathrm{CO}_{2}$ and temperature on the calculated 'safe' carrying capacity (Safe $C C$, Table 4). Locations in south-east Queensland had the lowest sensitivity to changes in rainfall and $\mathrm{CO}_{2}$ because of nitrogen limitation on pasture growth but warmer temperatures increased $\%$ gidays and hence increased 'safe' utilisation rate and Safe CC. The combined changes resulted in increases of 7 to $27 \%$ in Safe CC across rainfall scenarios ( $\pm 10 \%$ ) and south-east locations.

At central Queensland locations, the percentage changes in Safe $C C$ were equivalent to the imposed changes in rainfall ( $\pm 10 \%$ ). Doubling $\mathrm{CO}$, alone resulted in a 7 to $14 \%$ increase and compensated for the drier rainfall scenario when the two changes were imposed together. Warmer temperatures alone increased Safe CC (6 to 30\%) with considerable increases for the warmer, wetter scenario depending on location (16 to $44 \%$ ). The combined changes resulted in increases of 8 to $61 \%$ in Safe CC across rainfall scenarios $( \pm 10 \%)$ and locations in central Queensland.

For north-east Queensland locations, changes in Safe CC were directly related to changes in rainfall. Doubling $\mathrm{CO}_{2}$ alone increased Safe $C C$ by 9 to $20 \%$ whilst increased temperature resulted in reduced Safe $C C(-2$ to $-10 \%)$ especially under the warmer drier scenario depending on location $(-14$ to $-29 \%)$. The combined scenarios resulted in changes of -12 to $+18 \%$ in Safe CC across rainfall scenarios and locations. 


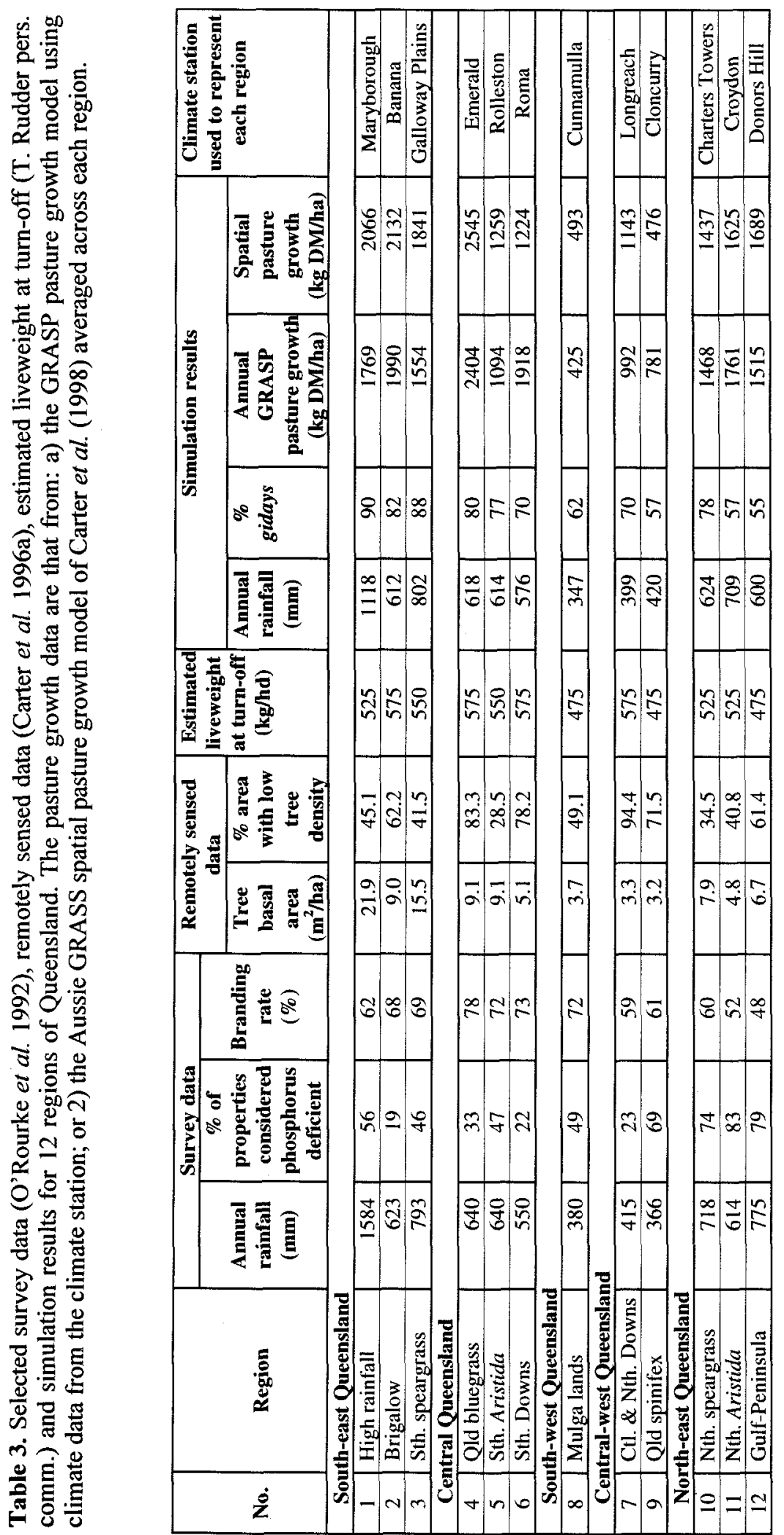




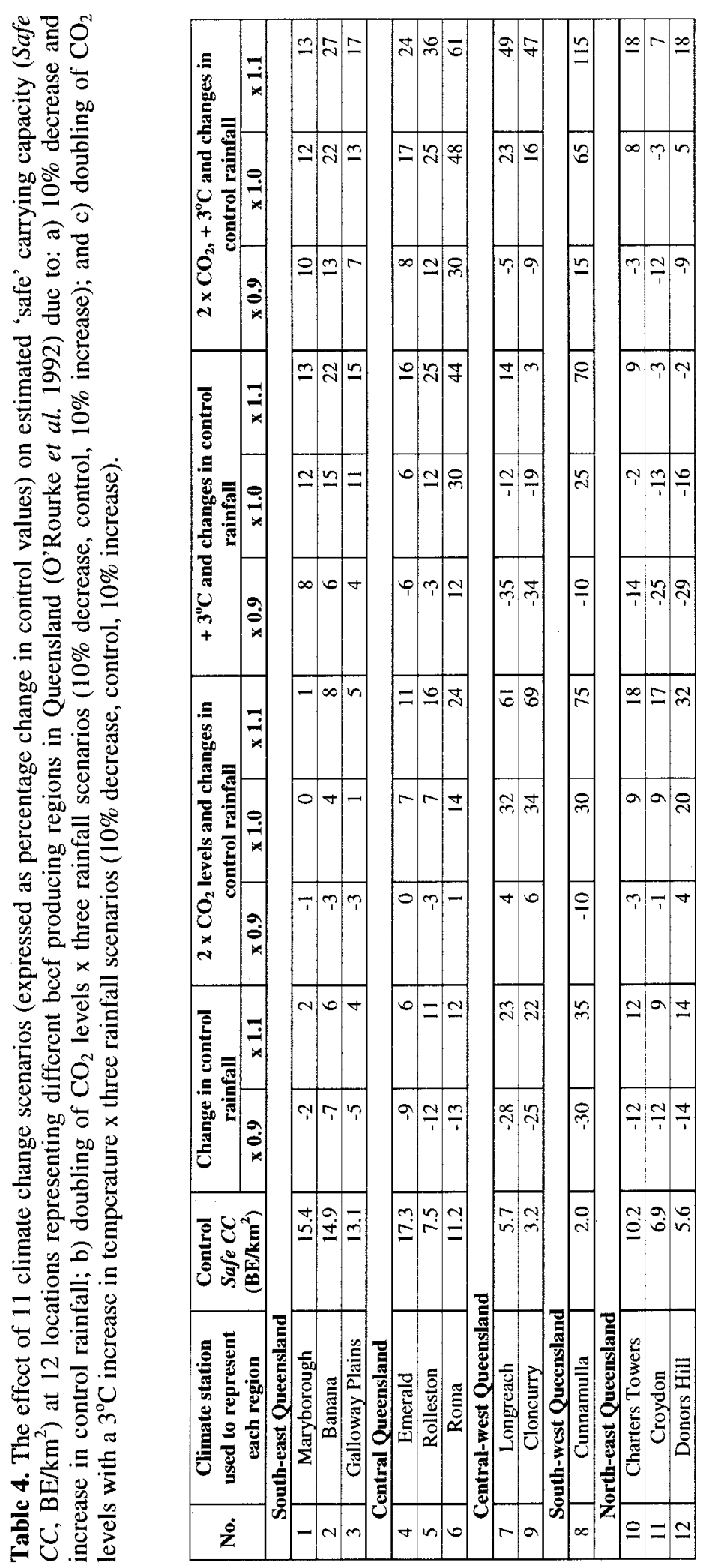


In central-west Queensland there was considerable amplification of the $\pm 10 \%$ rainfall change $(-25$ to $+23 \%)$ and strong positive effects of doubling $\mathrm{CO}(30 \%)$. Increased temperature had a negative effect depending on location $(-12$ to $-19 \%)$ and the combined change scenario effects ranged from -9 to $+49 \%$ across rainfall scenarios and locations.

For the site in the south-west, Safe $C C$ had the highest sensitivity to the $\pm 10 \%$ changes in rainfall $(-30$ to $+35 \%)$. Doubling $\mathrm{CO}_{2}$ and warmer temperatures resulted in strongly positive effects ( 30 and $25 \%$ respectively) and hence there was a very wide range of possible effects across the combined scenarios $(+15$ to $+115 \%)$. These effects reflect the major limitations of moisture and temperature on $\mathrm{C}_{4}$ grass growth in the south-west region (Mott et al. 1985).

A major finding in this case study was the mitigating effect of $\mathrm{CO}_{2}$ on the combined negative effects of lower rainfall and warmer temperatures on Safe CC particularly for locations in north-east and central-west Queensland where the average negative effect for five locations was reduced from -27 to $-7 \%$.

This simulation case study showed strong interactions between location and climate change scenarios. To some extent this is to be expected given that there is considerable variation in where and when pasture growth is limited by nitrogen, moisture or temperature. The application of the same climate change scenario across the 12 regions showed that there are both 'winners' and 'losers' in terms of 'safe' carrying capacity. Hence there is a need to assess the impacts on the industry across the State.

\section{Case study 3: Climate change impacts on Queensland's 'safe' carrying capacity}

To calculate the 'safe' carrying capacity for the whole of Queensland in beast equivalents ( $Q l d$ $C C$ ), the above results (Case study 2) were aggregated by weighting for the area of each of the 12 regions (calculated from Tothill and Gillies 1992). Because of the small area of the 'southern rolling downs' ( $2 \%$ of State), the bias in pasture growth resulting from the choice of rainfall station for this region (Table 4) did not contribute greatly to differences in calculated Qld CC. The advantage of representing Queensland as ' 12 points' was that a large number of sensitivity experiments could be rapidly performed, analysed (Table 5) and interpreted.

The State-wide model estimated Qld CC to be between 11.1 and 12.4 million BE depending on the 'safe' utilisation relationship used (Table 5). These modelled values compare well with previous estimates of Qld CC (12.7 million BE, Weston et al. 1981; 12.25 million BE, Weston 1988). Weston (1988) also reported that Qld CC accounting for current land use (sown pastures and crops), was estimated at 12.5 million. These estimates can also be compared with actual stock data as reported by ABS. Carter et al. (1996a) have converted ABS stock numbers to beef equivalents accounting for age, sex and species (i.e. sheep). Since 1970 beef equivalents have ranged from 7.6 to 11.6 million $\mathrm{BE}$ with a mean of 10.0 million $\mathrm{BE}$. The lower number reported by ABS compared to the above simulations may be the result of: 1) loss of carrying capacity due to resource degradation (Tothill and Gillies 1992); 2) over-estimates of actual area of properties utilised (O'Rourke et al. 1992); and 3) under-reporting of actual numbers to ABS, e.g. Dalrymple Shire (White 1997).

The survey results of O'Rourke et al. (1992) suggested that $15 \%$ of property areas on average were not utilised. When the areas of pasture community reported by Tothill and Gillies (1992), which were used in the calculation of Table 5 , were corrected for regional differences in proportion of property utilised, the simulated beef equivalents were in closer agreement with ABS numbers ( 9.4 and 10.5 million $\mathrm{BE}$ for $\% S U_{\text {propery }}$ and $\% S U_{\text {poimt }}$ calculations respectively). As yet the 'area' values most appropriate for a State-wide calculation are still to be resolved and for the purpose of the State-wide sensitivity calculation we have 


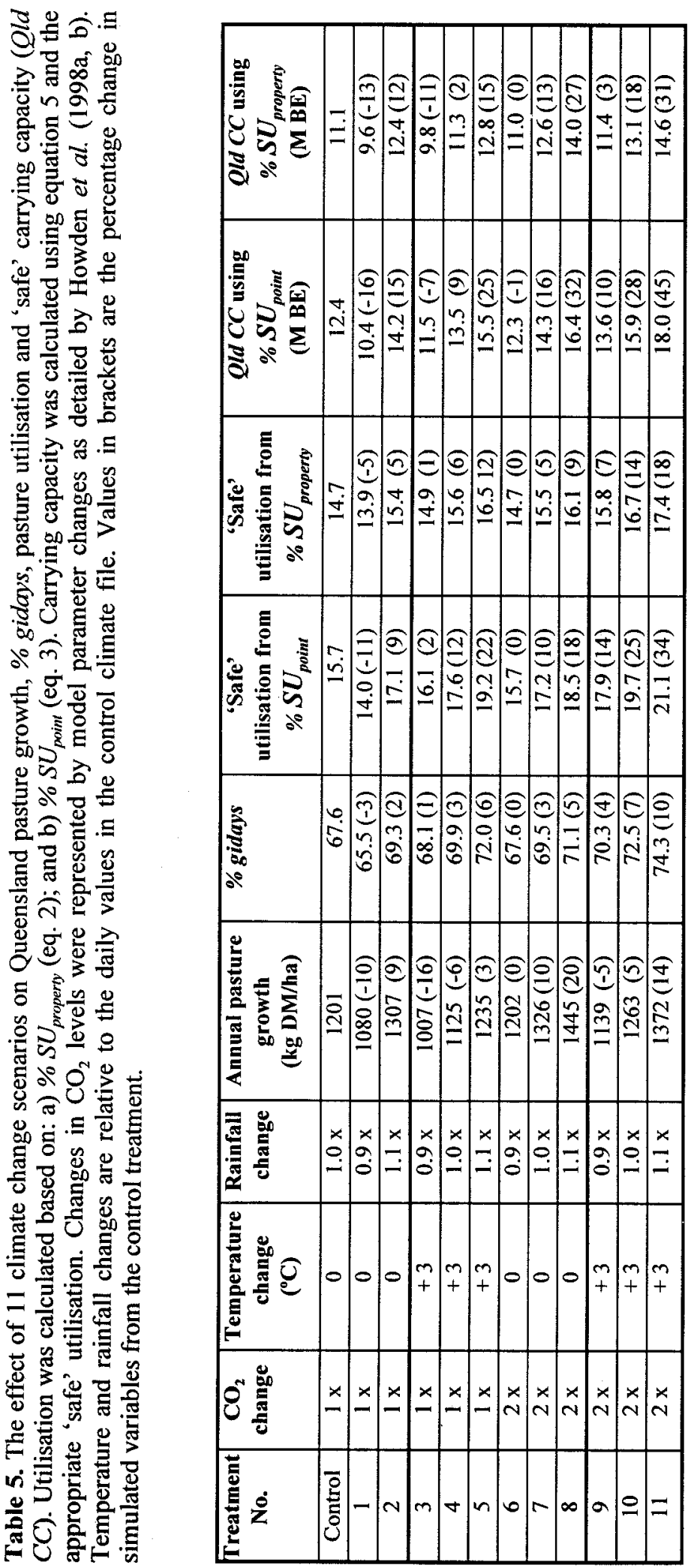


used the areas given by Tothill and Gillies (1992). The other possible causes of differences between simulated 'safe' carrying capacity and ABS numbers (resource degradation and/or under-reporting) have not been evaluated at this stage of model development.

\section{Simulation results: Case study 3}

The following results refer to those obtained using $\% S U_{\text {propery }}$ (equation 2) to estimate 'safe' carrying capacity for Queensland (Table 5). The simulated changes in State 'safe' carrying capacity as a result of changes in rainfall, $\mathrm{CO}_{2}$ and temperature reflect the impact of changes in $\%$ gidays on 'safe' utilisation more than the impact on pasture growth (e.g. Table 1). Changes in rainfall $( \pm 10 \%)$ resulted in similar changes in Qld CC $\left(-13\right.$ to $+12 \%$, Table 5). Doubling $\mathrm{CO}_{2}$ alone resulted in a $13 \%$ increase in Qld CC and compensated for the 'drier' rainfall scenario. Warmer temperatures alone had little effect $(+2 \%)$, amplified the effect of the wetter rainfall scenario $(+12 \rightarrow+15 \%)$ and slightly reduced the effect of the drier scenario $(-13 \rightarrow-11 \%)$. The combined effects of rainfall, $\mathrm{CO}_{2}$ and temperature ranged from +3 to $+31 \%$ across the range of rainfall scenarios.

The relationship between $\% S U_{\text {point }}$ and $\%$ gidays had a steeper slope and hence estimates of Qld CC obtained using $\% \mathrm{SU}_{\text {poim }}$ were more sensitive (Table 5) to changes in rainfall, $\mathrm{CO}_{2}$ and temperature than those reported above. For example, the combined effects on Qld CC using \% $S U_{\text {poim }}$ ranged from +10 to $+45 \%$ depending on rainfall scenario. Thus the choice of model of ' $\mathrm{safe}$ ' carrying capacity can, in some cases, be as large as the effects of plausible climate and $\mathrm{CO}_{2}$ changes considered alone. Nevertheless both calculations show that on a State-wide basis the potential negative effects of reduced rainfall and warmer temperature can be compensated by doubling $\mathrm{CO}_{2}$, and that large changes in State-wide carrying capacity are plausible (e.g. $+30,+45 \%)$.

\section{Discussion and conclusion}

The purpose of this paper was to review the ability of models to calculate the impact of climate change on Queensland grazing lands. The complexity of the biophysical basis of the grazing industries interacting with social and economic forces increases the difficulty of modelling such impacts. Despite this complexity, empirical models have been developed from current industry practice which explained a high proportion of regional variation in carrying capacity in terms of climate variation and were suitable for examining climate change scenarios. Although these models accounted for a high degree of the variation between regions, it would be expected that consideration of differences between pasture communities in key attributes such as potential nitrogen uptake, critical nitrogen content, water use efficiency (Day et al. 1997a), and pasture condition (Tothill and Gillies 1992) would further refine the models.

The models and information reviewed and developed in this study showed that native pasture growth and animal production can be limited by a wide range of factors such as moisture, temperature, nitrogen, phosphorus; and have a wide range of species responses (Day et al. 1997a). With the same climate scenario applied across the whole State with constant soil and pasture parameters, considerable variation in impacts occurred between regions (Table 4). More complex variation is to be expected when regional climate change scenarios are evaluated in combination with varying soil and pasture parameters. Hence there will be a greater need for extensively validated spatial models such as that of Carter et al. (1998) to aggregate the impacts at a State level and identify regions with large negative and positive effects. Further major priorities for spatial model development are in animal production (e.g. Hall 1996) combined with pest/disease/weed effects (Sutherst et al. 1996).

The sensitivity study of plausible climate change scenarios suggested that large impacts on 'safe' carrying capacity are possible $(-11$ to $>+30 \%)$ depending on model choice and $\mathrm{CO}_{2}$ effects. Of particular importance is the possibility that doubling $\mathrm{CO}_{2}$ may mitigate the 
potentially negative effects of the combined drier rainfall and warmer temperature scenario (from $-7 \rightarrow+3$ ). The $\mathrm{CO}_{2}$ parameterisation of the model was based on a conservative analysis of available information (Howden et al. 1998a, b). Experiments on relevant northern Australian species (grass and trees) are in progress, although as yet Free Air Carbon Exchange (FACE) experiments have not been conducted in Queensland. Given the potential sensitivity of Queensland carrying capacity to changes in $\mathrm{CO}_{2}$, and the importance of grazing industries to State production, FACE experiments on $\mathrm{CO}_{2}$ effects on native pastures should be a high priority.

The case studies were the first of their type and hence it is important to document their potential linitations to identify priorities for further work.

1. Thermal stress and liveweight gain. High temperatures and humidity have been shown to limit potential liveweight gain of cattle in the tropics during the wet season (Petty et al. 1998) probably through limits on heat dissipation reducing intake. Thus the inclusion of a temperature-humidity index (Kibler 1964) in equations simulating liveweight gain is a high priority. However, a major modelling issue is the interaction of nutrition and thermal stress and hence more mechanistic models (e.g. Howden and Turnpenny 1997) will be required to correctly account for the effect of thermal stress on liveweight gain. The effect of thermal stress on reproduction is also a major issue when considering the Queensland sheep industry. Similarly, the inclusion of production costs due to pests and diseases as reviewed in the systems analysis is a high priority.

2. Climate change scenario and carrying capacity. The simulation of carrying capacity assumes that climate change impacts on average pasture growth can be treated independently of impacts on 'safe' utilisation rates. This assumption is supported by the difference in'safe'utilisation rates in dry monsoonal climates to more benign sub-tropical climates (Table 2). However, interaction of socio-economic effects (e.g. distance to markets) and climate hazards (e.g. floods and droughts) may be correlated with the climatic indices derived in this paper and hence we have adopted a conservative approach (Table 5) to sensitivity analysis.

A number of known model limitations were also identified as high priorities for climate change impact assessment. Both nitrogen availability and morphological development (leaf/stem) are simplistically treated in GRASP and were not explicitly linked to climate variables (Howden et al. 1998b). The development of climate driven models of these processes is in progress and will allow a more mechanistic extrapolation of current data (Day et al. 1997a). Other important issues to be addressed include the dynamics of tree/grass interaction under increased $\mathrm{CO}_{2}$ and models of the interaction of climate change and resource deterioration/degradation on carrying capacity.

\section{Acknowledgements}

We would like to acknowledge the financial support of the Rural Industries Research and Development Corporation, Australian Greenhouse Office, National Climate Variability Program (administered by the Land and Water Resources Research and Development Corporation) and Meat and Livestock Australia (formerly Meat Research Corporation); and provision of unpublished grazing trial data by R. Roberton.

\section{References}

ABARE (1996). Australian commodity statistics 1996. ABARE, Canberra.

ARMCANZ (1996). Draft national strategy for rangeland management. Department of Environment Sports and Territories, Canberra.

Ash, A.J., McIvor, J.G., Corfield, J.P. and Winter, W.H. (1995). How land condition alters plant-animal relationships in Australia's tropical rangelands. Agric. Ecosys. Environ. 56: 77-92. 
Ash, A.J., Prinsen, J.H., Myles, D. J. and Hendricksen, R.E. (1982). Short-term effects of burning native pasture in spring on herbage and animal production in south-east Queensland. Proc. Aust. Soc. Anim. Prod. 14: 377-80.

Ash, A.J. and Stafford Smith, M. (1996). Evaluating stocking rate impacts in rangelands: Animals don't practice what we preach. Rangel. J. 18: 216-43.

Atzeni, M.G., Mayer, D.G. and Stuart, M.A. (1997). Evaluating the risk of the establishment of screwworm fly in Australia. Aust. Vet. J. 75: 743-5.

Bates, B.C., Jakeman, A.J., Charles, S.P., Sumner, N.R. and Fleming, P.M. (1996). Impact of climate change on Australia's surface water resources. In: Greenhouse: coping with climate change (Eds W.J. Bouma, G.I. Pearman, and M.R. Manning.) pp. 248-62. CSIRO, Australia.

Beale, I.F. (1975). Forage intake and digestion by sheep in the mulga zone of Queensland, Australia. Ph.D. Thesis, Colorado State University, Fort Collins.

Beale, I.F., Orr, D.M., Holmes, W.E., Palmer, N., Evenson, C.J. and Bowly, P.S. (1986). The effect of forage utilization levels on sheep production in the semi arid south west of Queensland. In: Rangelands: a resource under siege (Eds P.J. Joss, P.W. Lynch and O.B. Williams) p. 30. Australian Academy of Science, Canberra.

Bisset, W.J. (1962). The black spear grass (Heteropogon contortus) problem of the sheep country in central western Queensland. Queensl. J. Agric. Sci. 19: 189-207.

Bryan, J.H., Foley, D.H. and Sutherst, R.W. (1996). Malaria transmission and climate change in Australia. Med. J. Aust. 16: 345-7.

Burrows, W.H. (1995). Greenhouse revisited - land-use change from a Queensland perspective. Clim. Change Newsl. 7: 6-7.

Burrows, W.H. (1997). Effects of stocking rate, legume augmentation, supplements and fire on animal production and stability of native pastures. In: The North Australia Program: 1997 review of improving resource management projects. (Ed. B. Walker.) pp. 13-8. Meat Research Corporation, Sydney.

Buxton, R. and Stafford Smith, M. (1996). Managing drought in Australia's rangelands: Four weddings and a funeral. Rangel. J. 18: 292-308.

Campbell, B.D., McKeon, G.M., Gifford, R.M., Clark, H., Stafford Smith, D.M., Newton, P.C.D. and Lutze, J.L. (1996). Impacts of atmospheric composition and climate change on temperate and tropical pastoral agriculture. In: Greenhouse: coping with climate change (Eds W.J. Bouma, G.I. Pearman, and M.R. Manning.) pp. 171-89. CSIRO, Australia.

Campbell, B.D., Stafford Smith, D.M. and McKeon, G.M. (1997). Elevated $\mathrm{CO}_{2}$ and water supply interactions in grasslands: A pastures and rangelands management perspective. Global Change Biol. 3 : 177-87.

Carter, J.O., Flood, N.F., Danaher, T., Hugman, P. Young, R., Duncalfe, F., Barber, D., Flavel, R., Beeston, G., Mlodawski, G., Hart, D., Green, D., Richards, R., Dudgeon, G., Dance, R., Brock, D., Petty, D. and others (1996a). Development of data rasters for model inputs. In: Development of a national drought alert strategic information system, Volume 3, Final report on QPI 20 to Land and Water Resources Research and Development Corporation.

Carter, J.O., Flood, N.F., McKeon, G.M., Peacock, A. and Beswick, A. (1996b). Model framework, parameter derivation, model calibration, model validation, model outputs, web technology. In: Development of a national drought alert strategic information system, Volume 4, Final Report on QPI 20 to Land and Water Resources Research and Development Corporation.

Carter, J.O., Hall, W.B., Brook, K.D., McKeon, G.M., Day, K.A. and Paull, C.J. (1998). Aussie GRASS: Australian grassland and rangeland assessment by spatial simulation. In: Applications of seasonal climate forecasting in agricultural and natural ecosystems - the Australian experience (Eds G. Hammer, N. Nicholls and C. Mitchell) (in press). Kluwer Academic Press, Netherlands.

Chippendale, J.F. and Panetta, F.D. (1994). The cost of parthenium weed to the Queensland cattle industry. Plant Prot. Q. 9: 73-6.

CIG (1996). Climate change scenarios for the Australian region. Climate Impact Group, CSIRO Division of Atmospheric Research, Melbourne.

Clewett, J.F., Cavaye, J.M., Partridge, I.J., McKeon, G.M. and Scanlan, J.C. (1991). Sustaining productive pastures in the tropics, 12 . Decision support software as an aid to managing pasture systems. Trop. Grassl. 25: 159-64.

Condon, R.W. (1968). Estimation of grazing capacity on arid grazing lands. In: Land evaluation: Papers of a CSIRO symposium organised in cooperation with UNESCO (Ed. G. A. Stewart.) pp. 112-24. CSIRO Division of Land Research, Canberra.

Condon, R.W., Newman, J.C. and Cunningham, G.M. (1969). Soil erosion and pasture degeneration in central Australia. Part III - The assessment of grazing capacity. J. Soil Conserv. Serv. NSW. 25: 295321.

Day, K.A., McKeon, G.M. and Carter, J.O. (1997a). Evaluating the risks of pasture and land degradation in native pasture in Queensland. Final report for Rural Industries and Research Development Corporation project DAQ124A. 
Day, K.A., Scattini W.J. and Osborne, J.C. (1997b). Extending carrying capacity calculations to the central Burnett region of Queensland. In: DroughtPlan Working Paper No. 10. (Eds D.M. Stafford Smith, J.F. Clewett, A.D. Moore, G.M. McKeon and R. Clark). CSIRO, Alice Springs.

Denham, S.C. and Spreen, T.H. (1986). Introduction to simulation of beef cattle production. In: Simulation of beef cattle production systems and its use in economic analysis. (Eds T. H. Spreen and D. H. Laughlin.) pp. 39-61. Westview Press, Boulder.

Deutscher, N.C. (1959). The development of the cattle industry in Queensland 1840-1890. BA Honours Thesis. University of Queensland, Brisbane.

Farmer, J.N., Everist, S.L. and Moule, G.R. (1947). Studies in the environment of Queensland. 1, The climatology of semi-arid pastoral areas. Queensl. J. Agric. Sci. 4: 21-59.

Fensham, R.J. (1998). The influence of cattle grazing on tree mortality after drought in savanna woodland in north Queensland. Aust. J. Ecol. 23: 405-7.

Fitzpatrick, E.A. and Nix, H.A. (1970). The climatic factor in Australian grassland ecology. In: Australian grasslands (Ed. R.M. Moore) pp. 3-26. ANU Press, Canberra.

Flavel, N., Collins, D. and Menz, K. (1987). Climatic indexes for Australian grazing industries. Proceedings of the 30th Annual Conference of the Australian Agricultural Economics Society, pp. 115.

Foran, B.D. and Stafford Smith, D.M. (1991). Risk, biology and drought management strategies for cattle stations in central Australia. J. Environ. Manage. 33: 17-33.

Freer, M., Moore, A.D. and Donnelly, J.R. (1997). GRAZPLAN: decision support systems for Australian grazing enterprises. Il. The animal biology model for feed intake, production and reproduction and the GrazFeed DSS. Agric. Syst. 54: 77-126.

Gardener, C.J., Mclvor, J.G. and Williams, J.C. (1990). Dry tropical rangelands: solving one problem and creating another. Proc. Ecol. Soc. Aust. 16: 279-90.

Gillard, P. (1979). Improvement of native pasture with Townsville stylo in the dry tropics of sub-coastal northern Queensland. Aust. J. Exp. Agric. Anim. Husb. 19: 325-36.

Gillard, P. and Moneypenny, R. (1990). A decision support model to evaluate the effects of drought and stocking rate on beef cattle properties in northern Australia. Agric. Syst. 34: 37-52.

Goodall, D.W. (1969). Simulating the grazing system. In: Concepts and models of biomathematics: simulation techniques and methods. (Ed. F. Heinmets.) pp. 211-36. Marcel Dekker, New York.

Graetz, R.D., Walker, B.H. and Walker, P.A. (1988). The consequences of climatic change for seventy per cent of Australia. In: Greenhouse: planning for climate change (Ed. G.I. Pearman) pp. 399-420. CSIRO, Melbourne.

Gramshaw, D. (Ed.) (1995). 'Integrated management for sustainable forage-based livestock systems in the tropics.' Queensland Department of Primary Industries, Brisbane.

Gramshaw, D. and Lloyd, D. (1993). 'Grazing the north: creating wealth and sustaining the land.' Queensland Department of Primary Industries, Brisbane.

Hall, W.B. (1996) Near-real time financial assessment of the Queensland wool industry on a regional basis. Ph.D. thesis, University of Queensland, Brisbane.

Hattersley, P.W. (1983). The distribution of $C_{3}$ and $C_{4}$ grasses in Australia in relation to climate. Oecologia 57: 113-28.

Hendricksen, R.E., Rickert, K.G., Ash, A.J. and McKeon, G.M. (1982). Beef production model. Proc. Aust. Soc. Anim. Prod. 14: 208-10.

Herne, B. (1998). U.S. Cattle cycle is the key to rising prices. Brigaletter 32 (August): 1-2.

Hogan, J.P. (1996). Options for manipulating nutrition if feed supply is immutable. Aust. J. Agric. Res. 47: 289-305.

Holmes, W.E. (1988). 'Instructions for BREEDCOW and DYNAMA herd budgeting spreadsheet models: Versions 01-12-88.' Queensland Department of Primary Industries, Townsville.

Holmes, W.E. (1997). Making the change from bullocks. In: Marketing cattle to south-east Asia (Eds R. Kaus, J. Lapworth and R. Dunn) pp. 17-25. Queensland Department of Primary Industries, Brisbane.

Hooper, R.D. (1973). Forecasting shorn wool production per sheep shorn in Australia. Fibre Rev. 197273: 52-62.

Howden, S.M., McKeon, G.M., Walker, L., Carter, J.O., Conroy, J.P., Day, K.A., Hall, W.B., Ash, A.J. and Ghannoum, O. (1998a). Global change impacts on native pastures in south-east Queensland, Australia. Environ. Model. Software (in press).

Howden, S.M. and Turnpenny, J. (1997). Modelling heat stress and water loss of beef cattle in subtropical Queensland under current climates and climate change. Modsim '97 International Congress on Modelling and Simulation Proceedings, 8-11 December, University of Tasmania, Hobart, pp. 1103-8. 
Howden, S.M., Walker, L., McKeon, G.M., Hall, W.B., Ghannoum, O., Day, K.A., Conroy, J.P., Carter, J.O. and Ash, A.J. (1998b). Simulation of changes in $\mathrm{CO}_{2}$ and climate on native pasture growth. Final report for the Rural Industries Research and Development Corporation: Evaluation of the impact of climate change on northern Australian grazing industries (DAQ 139A), pp. 141-84.

Ivory, D.A. and Whiteman, P.C. (1978). Effect of temperature on growth of five subtropical grasses. I. Effect of day and night temperature on growth and morphological development. Aust. J. Plant Physiol. 5: 86-99.

Johnston, P.W., McKeon, G.M. and Day, K.A. (1996a). Objective "safe" grazing capacities for southwest Queensland Australia: Development of a model for individual properties. Rangel. J. 18: 244-58.

Johnston, P.W., Tannock, P.R. and Beale, I.F. (1996b). Objective 'safe' grazing capacities for south-west Queensland Australia: model application and evaluation. Rangel. J. 18: 259-69.

Jones, R.J., Coates, D.B. and McCaskill, M.R. (1990). Pasture and climatic effects on cattle liveweight gain from stylo-based pastures in the seasonally dry tropics. Proc. Aust. Soc. Anim. Prod. 18: 260-3.

Keeling, C.D., Chin, J.F.S. and Whorf, T.P. (1996). Increased activity of northern vegetation inferred from atmospheric $\mathrm{CO}_{2}$ measurements. Nature 382: 146-9.

Kibler, H.H. (1964). Environmental physiology and shelter engineering. LXVI. Various temperature and humidity combinations of Hollstein cattle as measured at constant $50^{\circ} \mathrm{F}$ and $80^{\circ} \mathrm{F}$ temperatures. University of Missouri Agricultural Experiment Station Research Bulletin No. 862.

Lindsay, M.D. and Mackenzie, J.S. (1997). Vector-borne diseases and climatic change in the Australasian region: major concerns and the public health response. In: Climate change in the Asia-Pacific (Eds $P$. Curson, C. Guest and E. Jackson) pp. 47-62. Greenpeace International/Australian Medical Association, Canberra.

Littleboy, M. and McKeon, G.M. (1997). Subroutine GRASP: Grass production model. Documentation of the Marcoola version of Subroutine GRASP. Appendix 2 of Evaluating the risks of pasture and land degradation in native pasture in Queensland. Final Project Report for Rural Industries and Research Development Corporation project DAQ124A.

Lloyd, P.L. and Burrows, W.H. (1988). The importance and economic value of native pastures to Queensland. In: Native pastures in Queensland: the resources and their management (Eds W.H. Burrows, J.C. Scanlan and M.T. Rutherford) pp. 1-12. Queensland Department of Primary Industries, Brisbane.

Logan, D. (1988). 'Where two rivers run: a history of Kilkivan shire.' Kilkivan Shire Council, Kilkivan.

Mackey, A.P. (Ed.) (1996). 'Prickly acacia (Acacia nilotica) in Queensland.' Queensland Department of Natural Resources, Brisbane.

Makin, J. (1992). 'The big run: the story of Victoria River Downs Station.' Weldon Publishing, Sydney.

Mannetje, L.'t. (1974). Relations between pasture attributes and liveweight gains on a subtropical pasture. Proceedings XII International Grassland Congress, Volume 3, Moscow, pp. 299-304.

McCaskill, M.R. (1991). Prediction of cattle growth rates in northern Australia from climate information. Conference on Agricultural Meteorology, Bureau of Meteorology, Melbourne, pp. 85-8.

McCaskill, M.R. and McIvor, J.G. (1993). Herbage and animal production from native pastures and pastures oversown with Stylosanthes hamata 2. Modelling studies. Aust. J. Exp. Agric. 33: 571-9.

McCosker, T. and Winks, L. (1994). 'Phosphorus nutrition of beef cattle in northern Australia.' Queensland Department of Primary Industries, Brisbane.

McCown, R.L. (1980-81). The climatic potential for beef cattle production in tropical Australia: Part 1 Simulating the annual cycle of liveweight change. Agric. Syst. 6: 303-17.

McCown, R.L., Gillard, P., Winks, L. and Williams, W.T. (1981). The climatic potential for beef cattle production in tropical Australia: Part 2 - Liveweight change in relation to agroclimatic variables. Agric. Syst. 7: 1-10.

Mclvor, J. and Moneypenny, R. (1995). Evaluation of pasture development options for beef production systems in the semi-arid tropics: Model development. Agric. Syst. 49: 45-67.

McKeon, G.M., Ash, A.J., Hall, W.B. and Stafford Smith, D.M. (1998a). Simulation of grazing strategies for beef production in north-eastern Queensland. DroughtPlan Working Paper No. 8, Queensland Department of Natural Resources, Brisbane.

McKeon, G.M., Charles, S.P., Bates, B.C. and Hall, W.B. (1998b). Methods for evaluating climate change impacts on pasture growth. Final report for the Rural Industries Research and Development Corporation: Evaluation of the impact of climate change on northern Australian grazing industries (DAQ 139A), pp. 113-40.

McKeon, G.M., Day, K.A., Howden, S.M., Mott, J.J., Orr, D.M., Scattini, W.J. and Weston, E.J. (1990). Northern Australian savannas: management for pastoral production. J. Biogeogr. 17: 355-72.

McKeon, G.M., Hall, W.B., Crimp, S.J., Howden, S.M., Stone, R.C. and Jones, D.A. (1998c). Climate change in Queensland's grazing lands. I. Approaches and climatic trends. Rangel. J. 20(2): 151-76.

McKeon, G.M. and Rickert, K.G. (1984). A computer model of the integration of forage options for beef production. Proc. Aust. Soc. Anim. Prod. 15: 15-9. 
McKeon, G.M., Rickert, K.G., Robbins, G.B., Scattini, W.J. and Ivory, D.A. (1980). Prediction of animal performance from simple environmental variables. Fourth Biennial Conference, Simulation Society of Australia, pp. 9-16.

McKeon, G.M., Rickert, K.G. and Scattini, W.J. (1986). Tropical pastures in the farming system: case studies of modelling integration through simulation. Proceedings of Third Australian Conference on Tropical Pastures (Eds G.J. Murtagh and R.M. Jones) pp. 91-100. Tropical Grassland Society, Brisbane.

McLean, R.W., Winter, W.H., Hendricksen, R.E. and Coates, D.B. (1990). Phosphorus and beef production in northern Australia, 6. Dietary attributes and their relation to cattle growth. Trop. Grassl. 24: 197-208.

McLennan, S.R., Hendricksen, R.E., Beale, I.F., Winks, L., Miller, C.P. and Quirk, M.F. (1988). The nutritive value of native pastures to Queensland. In: Native pastures in Queensland: the resources and their management (Eds W.H. Burrows, J.C. Scanlan and M.T. Rutherford) pp. 125-60. Queensland Department of Primary Industries, Brisbane.

McLeod, R.S. (1995). Costs of major parasites to the Australian livestock industries. Int. J. Parasitol. 25: 1363-7.

McMeniman, N.P., Beale, I.F. and Murphy, G.M. (1986a). Nutritional evaluation of south-west Queensland pastures. I The botanical and nutrient content of diets selected by sheep grazing on Mitchell grass and mulga / grassland associations. Aust. J. Agric. Res. 37: 289-302.

McMeniman, N.P., Beale, I.F. and Murphy, G.M. (1986b). Nutritional evaluation of south-west Queensland pastures. II The intake and digestion of organic matter and nitrogen by sheep grazing on Mitchell grass and mulga grassland associations. Aust. J. Agric. Res. 37: 303-14.

McMichael, A.J., Haines, A., Slooff, R. and Kovats, S. (Eds.) (1996). 'Climate change and human health.' World Health Organisation, Geneva.

Moore, A.D., Mayer, D.G., Pepper, P.M. and Freer, M. (1995). Modelling of research data on reproduction and mortality of cattle and sheep. DroughtPlan Working Paper No. 5.

Moore, J.L., Howden, S.M., McKeon, G.M., Carter, J.O. and Scanlan, J.C. (1997). A method to evaluate greenhouse gas emissions from sheep grazed rangelands in south-west Queensland. Modsim '97 International Congress on Modelling and Simulation Proceedings, 8-11 December, University of Tasmania, Hobart, pp. 137-142.

Mott, J.J., Tothill, J.C. and Weston, E.J. (1981). Animal production for the native woodlands and grasslands of northern Australia. J. Aust. Inst. Agric. Sci. 47: 132-41.

Mott, J.J., Williams, J., Andrew, M.H. and Gillison, A.N. (1985). Australian savanna ecosystems. In: Ecology and management of the worlds savannas (Eds J.C. Tothill and J.J. Mott) pp. 56-82. Australian Academy of Science, Canberra.

Myneni, R.B., Keeling, C.D., Tucker, C.J., Asrar, G. and Nemani, R.R. (1997). Increased plant growth in the northern high latitudes from 1981 to 1991 . Nature 386: 698-702.

O'Rourke, P.K., Winks, L. and Kelly, A.M. (1992). 'North Australia beef producer survey 1990. Queensland Department of Primary Industries and the Meat Research Corporation, Brisbane.

Orr, D.M. (1986). Factors affecting the vegetation dynamics of Astrebla grasslands. Ph.D. Thesis, University of Queensland, Brisbane.

Partridge, I. (1992). 'Managing native pastures; a graziers guide.' Queensland Department of Primary Industries, Brisbane.

Partridge, I. (1993). 'Managing southern speargrass: a graziers guide.' Queensland Department of Primary Industries, Brisbane.

Petty, S.R., Poppi, D.P. and Triglone, T. (1998). Effect of maize supplementation, seasonal temperature and humidity on the liveweight gain of steers grazing irrigated Leucaena leucocephala / Digitaria eriantha pastures in north-west Australia. J. Agric. Sci. (Camb) 130: 95-105.

Poppi, D.P., Minson, D.J. and Ternouth, J.H. (1981). Studies of cattle and sheep eating leaf and stem fractions of grasses. III The retention time in the rumen of large feed particles. Aust. J. Agric. Res. 32: 123-37.

Reid, G.K.R. and Thomas, D.A. (1973). Pastoral production, stocking rate and seasonal conditions. $Q$. Rev. Agric. Econ. 26: 217-27.

SCA (1990). 'Feeding standards for Australian livestock: Ruminants.' CSIRO, Melbourne.

Scanlan, J.C., Hinton, A.W., McKeon, G.M., Day, K.A. and Mott, J. J. (1994). Estimating safe carrying capacities of extensive cattle-grazing properties within tropical, semi-arid woodlands of north-eastern Australia. Rangel. J. 16: 64-76.

Shaw, W.H. (1957). Bunch spear grass dominance in burnt pastures in south-eastern Queensland. Aust. J. Agric. Res. 8: 325-34.

Siebert, B.D. and Hunter, R.A. (1977). Prediction of herbage intake and liveweight gain of cattle grazing tropical pastures from the composition of the diet. Agric. Syst. 2: 198-208. 
Specht, R.L. and Specht, A. (1995). Global warming: Predicted effects on structure and species richness of Mediterranean ecosystems in southern Australia. In: Time scales of biological responses to water constraints (Eds J. Roy, J. Aronson and F. di Castri.) pp. 215-37. SPB Academic Publishing, Amsterdam.

Squires, V.R. and Siebert, B.D. (1983). Botanical and chemical components of the diet and liveweight change in cattle on semi-desert rangeland in central Australia. Aust. Rangel. J. 5: 28-34.

Stafford Smith, M., Buxton, R., McKeon, G. and Ash, A. (1998). Seasonal climate forecasting and the management of rangelands: Do production benefits translate into enterprise profits? In: Applications of seasonal climate forecasting in agricultural and natural ecosystems - the Australian experience (Eds $G$. Hammer, N. Nicholls and C. Mitchell.) (in press). Kluwer Academic Press, Netherlands.

Stafford Smith, D.M. and Foran, B.D. (1990). RANGEPACK: the philosophy underlying the development of a microcomputer-based decision support system for pastoral land management. J. Biogeogr. 17: 541-6.

Stafford Smith, M. and Foran, B. (1992). An approach to assessing the economic risks of different drought management tactics on a South Australian pastoral sheep station. Agric. Syst. 39: 83-105.

Stafford Smith, M. and McKeon, G.M. (1998). Assessing the historical frequency of drought events on rangelands grazing properties: Case studies. Agric. Syst. (in press).

Sutherst, R.W. (1990). Impact of climate change on pests and diseases in Australia. Search 21: 230-2.

Sutherst, R.W., Yonow, T., Chakraborty, S., O'Donnell, C, and White, N. (1996). A generic approach to defining impacts of climate change on pests, weeds and diseases in Australia. In: Greenhouse: coping with climate change (Eds W.J. Bouma, G.I. Pearman and M.R. Manning) pp. 281-307. CSIRO, Melbourne.

Tothill, J.C. and Gillies, C. (1992). The pasture lands of northern Australia: Their condition, productivity and sustainability. Tropical Grasslands Society of Australia Occasional Publication No. 5.

Weston, E.J. (1988). The Queensland environment. In: Native pastures in Queensland: the resource and their management (Eds W.H. Burrows, J.C. Scanlan and M.T. Rutherford) pp. 21-33. Queensland Department of Primary Industries, Brisbane.

Weston, E.J., Harbison, J., Leslie, J.K., Rosenthal, K.M. and Mayer, R.J. (1981). Assessment of the agricultural and pastoral potential of Queensland. Map No. 3; Native pasture communities. Queensland Department of Primary Industries, Agricultural Branch, Technical Report No. 27, Brisbane.

White, B.J. (1972). Supply projections for the Australian beef industry. Rev. Market. Agric. Econ. 40: 112.

White, B.J. (1978). A simulation based evaluation of Queensland's northern sheep industry. James Cook University, Department of Geography, Monograph Series No. 10, Townsville.

White, M.E. (1997). 'Listen...our land is crying: Australia's environment: problems and solutions.' Kangaroo Press, Sydney.

Whybrow, T. (1997). Outlook, Queensland Primary Industries. Report for the 1997 year (as at March 1997). Department of Primary Industries, Drought and Rural Development.

Wicksteed, L.T. (1980). A model of beef production systems - central sub-coastal speargrass zone of Queensland. Proc. Aust. Soc. Anim. Prod. 13: 361-4.

Wilson, J.R. and Mannetje, L.'t (1978). Senescence, digestibility and carbohydrate content of buffel grass and green panic leaves in swards. Aust. J. Agric. Res. 29: 503-16.

Manuscript received 12 August 1998, accepted 11 October 1998 